\title{
Sedimentological Characterization of the Pre-Santonian Siliciclastic Deposits of Lower Benue Trough, Southeastern Nigeria
}

\author{
Olubunmi C. Adeigbe ${ }^{1} \&$ O. C. Oruene ${ }^{1}$ \\ ${ }^{1}$ Department of Geology, University of Ibadan, Ibadan, Nigeria \\ Correspondence: Olubunmi C. Adeigbe, Department of Geology, University of Ibadan, Ibadan, Nigeria. Tel: \\ 234-802-821-8932. E-mail: olukris2009@gmail.com
}

\author{
Received: July 13, 2012 Accepted: July 30, 2012 Online Published: October 9, 2012 \\ doi:10.5539/esr.v2n1p105 URL: http://dx.doi.org/10.5539/esr.v2n1p105
}

\begin{abstract}
The study which involves forty-one (41) sandstone samples' collected from the area delimited by longitudes $7^{\circ} 00^{\prime} \mathrm{E}$ and $8^{\circ} 30^{\prime} \mathrm{E}$ and latitudes $5^{\circ} 00^{\prime} \mathrm{N}$ and $6^{\circ} 30^{\prime} \mathrm{N}$, entailed evaluating and characterizing these sediments. Detailed field studies to establish the lithostratigraphy was carried out and fresh samples were subjected to petrographic, granulometric and heavy mineral analyses.

Field observations revealed that the sandstones of the Awi Formation are angular to subangular, feldspathic, and generally fines upward and Amaseri are calcareous, indurated and laterally extensive. Agbani Sandstone consists of thick vertical sequences of ferruginized and indurated sandstones. Granulometric study shows medium to coarse-grained $(0.78-1.30 \Phi)$, poorly to moderately sorted $(0.87-1.19 \Phi)$, coarse to strongly fine skewed $(-0.17-0.57 \Phi)$ and very platykurtic to leptokurtic $(0.66-1.31 \Phi)$. This indicates mostly high energy condition and this is characteristic of fluvial environments. Petrographic studies for Awi samples indicate that they are texturally immature to submature, subarkosic arenites from a continental block provenance, while Amaseri Sandstones are texturally submature sublitharenites from a recycled orogen provenance. Agbani Sandstones are texturally immature to mature subarkosic arenites, sublitharenites and quartz arenites. Heavy mineral studies revealed zircon, tourmaline, rutile and hornblende to be common to all formations, sillimanite, kyanite, garnet, and staurolite are mostly common to Awi and Amaseri Sandstones while Agbani Sandstone has a dominance apatite with spinel. This suite of minerals suggests an acid igneous rock to typical dynamothermal metamorphic rock sources. The ZTR indices (74.0-94.4\%) indicate mineralogically mature sediments.

The study established that the pre- Santonian siliciclastic sequences of the Lower Benue Trough are texturally immature to mature and compositionally submature to supermature products of a continental block and recycled orogenic provenance under humid climates and deposited in fluvial to tidally influenced fluvial environments with high to moderate energy conditions humid climates which are deposited under high to moderate energy conditions.
\end{abstract}

Keywords: Awi Formation, Amaseri Sandstone, Agbani Sandstone, ZTR index

\section{Introduction}

The Benue Trough is defined as an Intracontinental Cretaceous basin about $1000 \mathrm{~km}$ in length stretching in NE-SW direction and resting unconformably upon the Precambrian Basement (Benkhelil et al., 1989). Offodile, (1989) stated that geologically, the Benue Trough consists of a linear stretch of sedimentary basin running from about the present confluence of the River Niger and Benue to the northeast and bounded roughly by the Basement Complex areas north and south of the Benue River (Figure 1). 


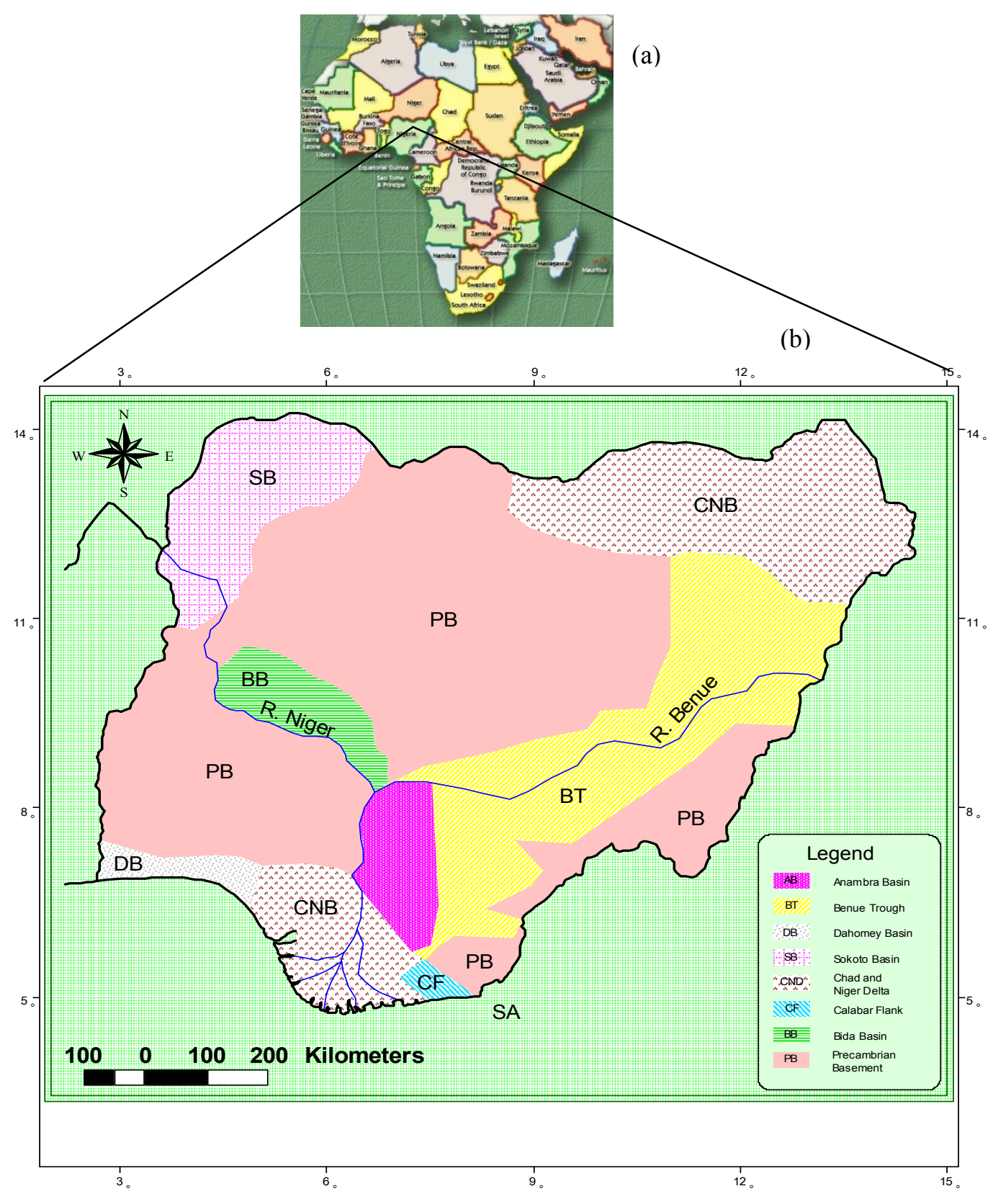

Figure 1. (a) Map of Africa showing Nigeria; (b) Map showing Nigerian basement complex and sedimentary basins. Note the trend and structure of the Benue Trough (BT)

There are several views about the evolution of this sedimentary basin but most agreed that the evolution of the Benue Trough is intimately connected to that of the South Atlantic ocean and that it is the failed arm of the Gulf of Guinea, South Atlantic and Benue Mesozoic triple junction whose center is occupied by the Niger Delta (Grant, 1971; Burke et al., 1972). The rift nature of the Benue Trough was first suggested by King (1950), but subsequently, several contradicting views were proposed (Freeth, 1990). Despite these diverse views, the most widely accepted is that proposed by Olade (1975), Burke (1976), Ofoegbu et al. (1990), and Murat (1972).

Though, some aspects of the sedimentology and stratigraphy of the pre-Santonian siliciclastic sequences within the Lower Benue Trough has been investigated by several authors (Reyment, 1965; Dessauvagie, 1972; Murat, 1972; Petters, 1983; Asseez, 1989; Kogbe, 1989; Benkhelil et al., 1989; Amajor, 1990; Obaje et al., 1999; Nton, 1999). However, the present study focuses on the holistic approach to field observations and sedimentological characterization of outcrop sections of the Awi Formation along Calabar-Ikom Expressway, Amaseri Sandstone in Amaseri Town, and Agbani Sandstone at Ugwueme and Ugwuokwute (Figure 2). The study provides detailed 
geology, lithologs, and lithologic descriptions of these sections, evaluate the textural and mineralogical characteristics of these sandstone units and ascertain their depositional environment, provenance and predicting the nature and state of the energy of the medium that transported and deposited them.

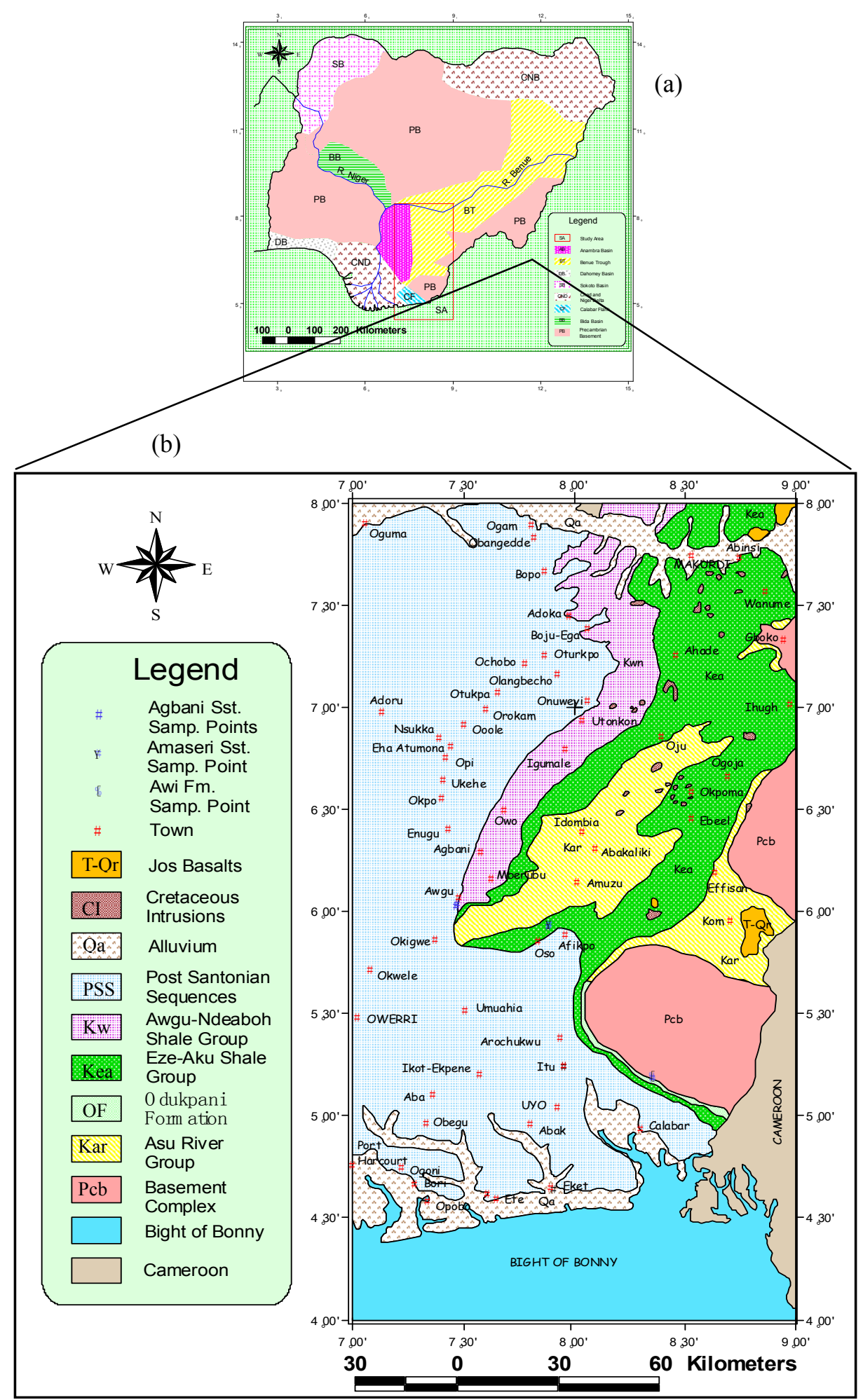

Figure 2. (a) Map of Nigeria showing sedimentary basins with the southeastern sedimentary basins outlined with a box. (b) Geologic map of southeastern Nigeria showing the lower Benue trough and outcrop locations of the present study (Modified after Okezie, 1984) 


\section{Stratigraphic Setting}

The sedimentary succession in the Lower Benue Trough is predominantly pre-Santonian in age and has been established as the Asu River Group, Eze-Aku Group, and the Awgu Formation (Reyment, 1965; Murat, 1972; and Petters, 1978). According to Asseez (1989), the oldest sedimentary rocks of Southern Nigeria consist of non-fossiliferous, arkosic; gravelly, poorly-sorted, commonly cross-bedded sandstones of probable Albian age derived from the Basement Complex and are exposed in Abakaliki and Calabar areas. For the purpose of this work, the work of Petters and Ekweozor (1982) and Petters (1983) on stratigraphy of the Lower Benue Trough will be adopted (Figure 3). These authors reported the Asu River Group as the initial clastic fill in the southern Benue Trough. It is about 9,800ft (3000 m) thick and comprises of basal arkosic sandstones of the Awi and Mamfe Formations; middle marine shales (Abakaliki Shale); karstic limestones and upper regressive sandstone (Awe Formation).

The Awi Formation in the Calabar area is made up of continental clastics, consisting of a fluvio-deltaic sequence of cross-bedded sandstones, siltstones, mudstones, conglomerates, and claystones (Nton, 1999). This unit overlies the Precambrian Oban Massif unconformably. The Abakaliki Shales in the Abakaliki area have being known to consist not only of shales but in addition, dark micaceous sandy shale, siltstones and fine-grained sandstone with rich ammonite fauna which indicate Albian age (Asseez, 1989). Overlying the Asu River group is the Cross River Group which includes shales, limestones, and intertonguing sandstones previously assigned to the Eze-Aku Group and Awgu Formation. These sandstones include Makurdi, Agala, Amaseri (lateral equivalents of Eze-Aku Shale) and Agbani Sandstones [lateral equivalent of Awgu Shale] (Murat, 1972; Offodile, 1976; Hoque, 1977; Banerjee, 1980). The shales and limestones of both Eze-Aku and Awgu Formation are referred to as Nkalagu Formation by Petters and Ekweozor (1982). Deposition of the Cross River Group is taught to have occurred during the late Cenomanian to early Santonian marine transgression.

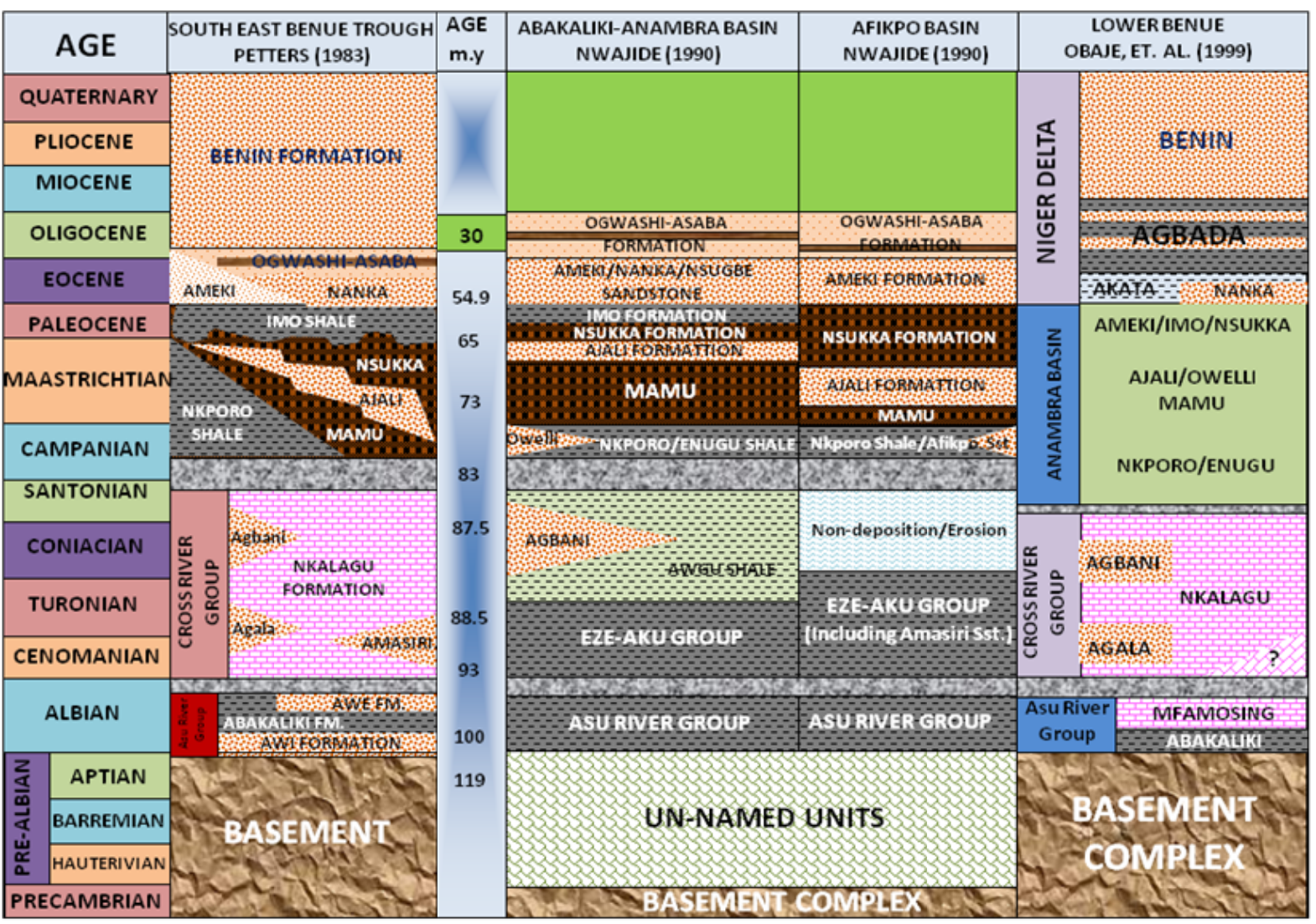

Figure 3. Stratigraphy of southeastern Nigeria Sedimentary Basins adapted from several authors

Sandstone ridges of Amaseri Sandstone are exposed near Ugep on the eastern side of the Cross River plain and in Amaseri town near Afikpo. Amaseri Sandstone was deposited as the continental and paralic facies of local 
delta complexes, with sediments having been derived from the Basement complex in areas of Ogoja while the Eze-Aku Shale may represent the prodelta clays and deeper water deposits associated with these complexes (Whiteman, 1980). The Eze-Aku Group grades into the marine Awgu Shales which consists essentially of grey-blue shales with subordinate limestone bands and calcareous sandstone. Agbani Sandstone which is the lateral equivalent of the Awgu Shales is made up of medium to coarse grained bioturbated and cross-bedded sandstones and laminated brownish clays. This depositional cycle was interrupted by the Santonian tectonic movement that folded and faulted the sediments in the trough. The Santonian folding was accompanied by extensive magmatic activity resulting in the formation of extrusive and intrusive igneous bodies which increase in amount and diversity from the Northeast to Southwest of the basin. Based on stratigraphic evidence, the total thickness of the entire sedimentary pile or depth to the Basement in the Lower Benue Trough as estimated from the thicknesses of individual units is given as $4.8 \mathrm{~km}$ (Burke et al., 1972; Ofoegbu et al., 1991).

\section{Methodology}

The methodology adapted in this work is divided into two sections; field observations and laboratory analysis.

\subsection{Field Observations}

Forty-one fresh sandstone (spot samples) were collected from four outcrops in three different localities. Samples collected from Location 1 (Calabar-Ikom Road) are representative of the Awi Formation (Figure 4) while samples from Location 2 (along Amaseri-Okposi road, close to Amaseri Crushed Stone Industry) are representative of Amaseri Sandstone (Figure 8). All samples collected from Locations 3 (Ugwueme) and 4 (Ugwuokwute) belong to the Agbani Sandstone unit (Figures 10 and 13).

It was observed in almost all the outcrops studied that most of their sedimentary structures have been destroyed or obliterated by weathering but those still identified were measured, described and photographed.

\subsection{Laboratory Analysis}

Laboratory studies include; granulometric analysis and petrographic studies involving thin sections and heavy minerals analyses.

\subsubsection{Granulometric Analysis}

Nine (9) representative samples collected from the field were subjected to sieve analysis. Four (4) samples were collected from Awi Formation, one (1) sample from the top of Amaseri Sandstone and four (4) samples from several horizons in the Agbani Sandstone. These samples were dried, disaggregated and 100gm of each sample weighed. These samples were sieved using an automated Endecott's Sieve Shaker and a set of sieve meshes ranging from very coarse sand size $(1 \mathrm{~mm})$ to very fine sand size $(75 \mu \mathrm{m})$.

The statistical parameters calculated were based on Folk and Ward (1957), Sahu (1964) and Friedman (1967). They include univariate parameters (mean size, skewness, sorting and kurtosis), bivariate and multivariate parameters. Moreso, the dip and azimuth of twenty five foreset planes of planar cross beds measured from the basal cross bedded section of the Agbani Sandstone were analyzed using variable constraints system by calculating the Mean Vector Azimuth (MVA) for the group of data collected from the field in order to ascertain the "mean vector" or specific flow direction of the transporting and depositional medium as well as paleocurrent pattern of the Agbani Sandstone.

\subsubsection{Petrography}

(a) Thin Section Petrography: Sixteen samples collected from different outcrop locations were selected for thin section petrography. Three samples were collected from Awi, two from Amaseri, and eleven from Agbani. Indurated samples were mounted directly after cutting while loosely consolidated were impregnated with epoxy resin before cutting and mounting on slides and polished to a thickness of approximately $0.03 \mathrm{~mm}$. Sandstone classification was based on Folk (1968), paleotectonic and paleoclimatic settings were determined based on Dickinson et al. (1983), Dickinson and Suczek (1979) and Suttner et al. (1981) respectively.

(b) Heavy Mineral Analysis: Sixteen samples were used. Three belong to Awi Formation, two from Amaseri Sandstone while eleven belong to Agbani Sandstone. Dried samples were disaggregated, weighed (50 gm), and sieved through a $300 \mu \mathrm{m}$ sieve mesh. 10 gm of the sieved sample is pre-treated with dil. $\mathrm{HCl}$ to remove any carbonates and washed with water to remove any clay present. Only $5 \mathrm{gm}$ of pre-treated sample was separated using bromoform in a separating funnel. The separated heavy minerals are then rinsed with acetone, allowed to dry, and then mounted on slides. Grains of both opaque and non-opaque minerals were counted using strips of masking tape mimicking the ribbon technique of Galehouse (1971). The counts of individual minerals identified are then tabulated and the ZTR indices for all samples determined based on Hubert (1962). 


\section{Results and Interpretations}

\subsection{Field Data Interpretation}

\section{Location 1: Along Calabar-Ikom Road (N05 10'59.1", E008 21'16.2" and elevation: 96 m)}

The log plot of this exposure shows that the overall thickness of this sequence is about $2.9 \mathrm{~m}$ and its basal unit lies unconformably on weathered granite gneiss belonging to the Basement of the Oban Massif (Figure 4 and Figure 5).

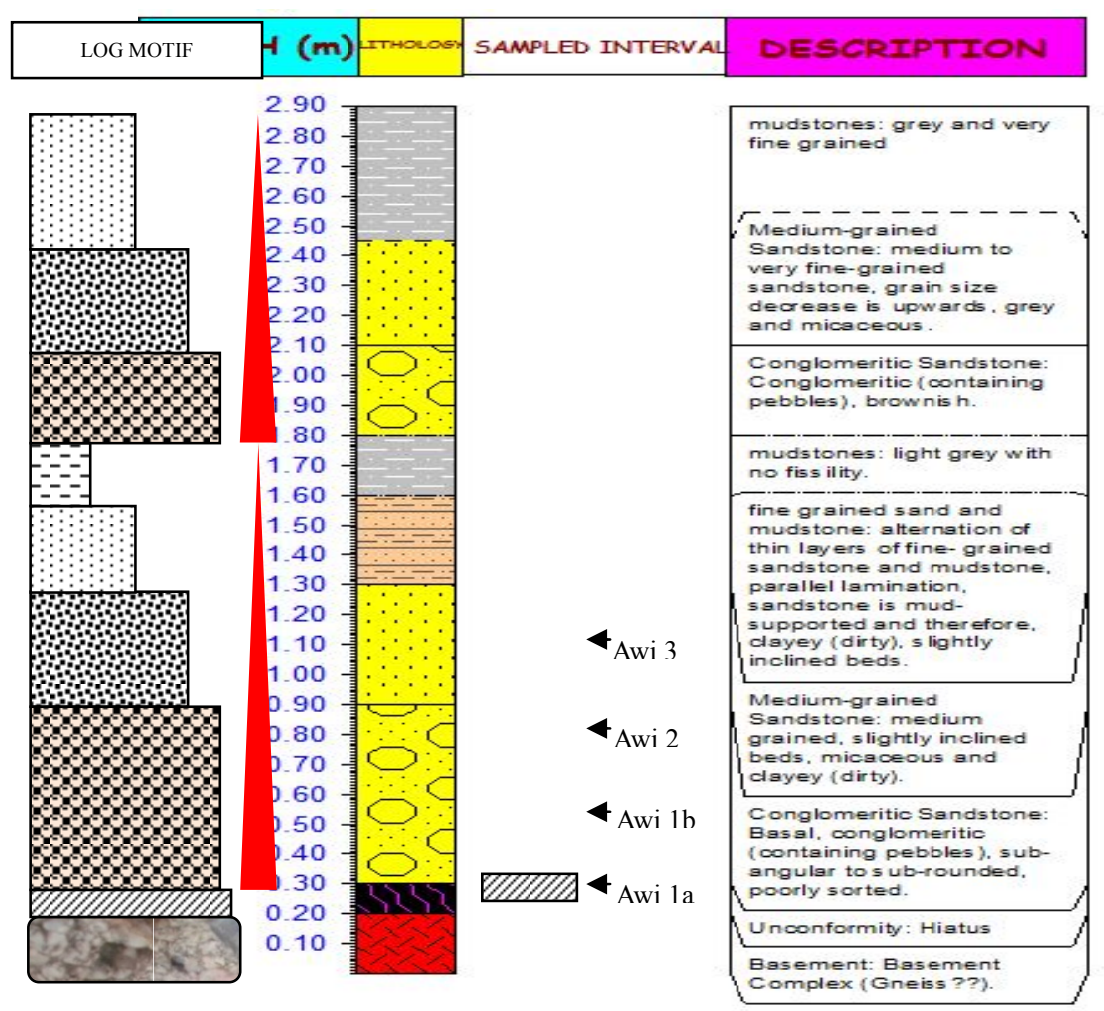

Figure 4. Log plot for Awi Formation along Calabar-Ikom road

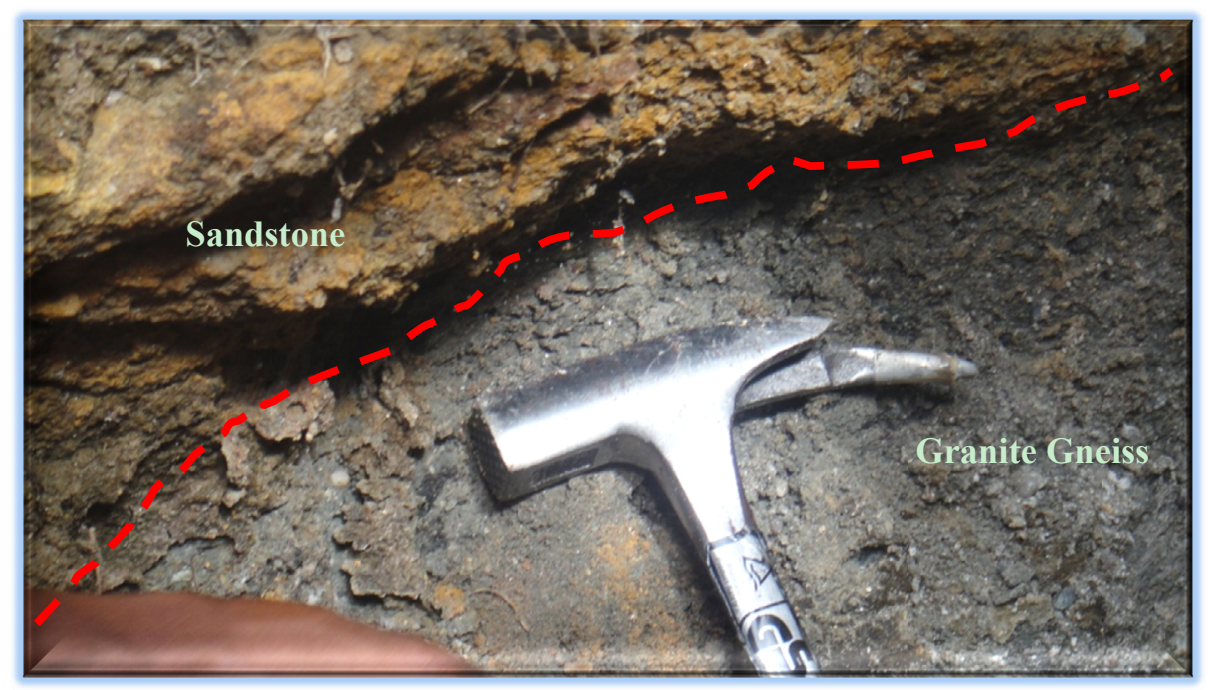

Figure 5. Contact between basement rocks and overlying conglomeritic sandstone of the Awi Formation along Calabar-Ikom road 
The basal conglomeritic brownish sandstone unit is about $0.6 \mathrm{~m}$ thick, contains pebbles and is poorly sorted with angular to sub-angular grains. Overlying this unit is brown-orange colored, coarse-medium grained sandstone that is $0.4 \mathrm{~m}$ thick, micaceous, feldspathic and dirty, and its upper section shows lamination. This unit grades into a $0.3 \mathrm{~m}$ thick mud-supported, fine grained, and dirty (clayey) sandstone. This unit is ripple-laminated and shows an alternation between grayish-green and orange colored beds (Figure 6).

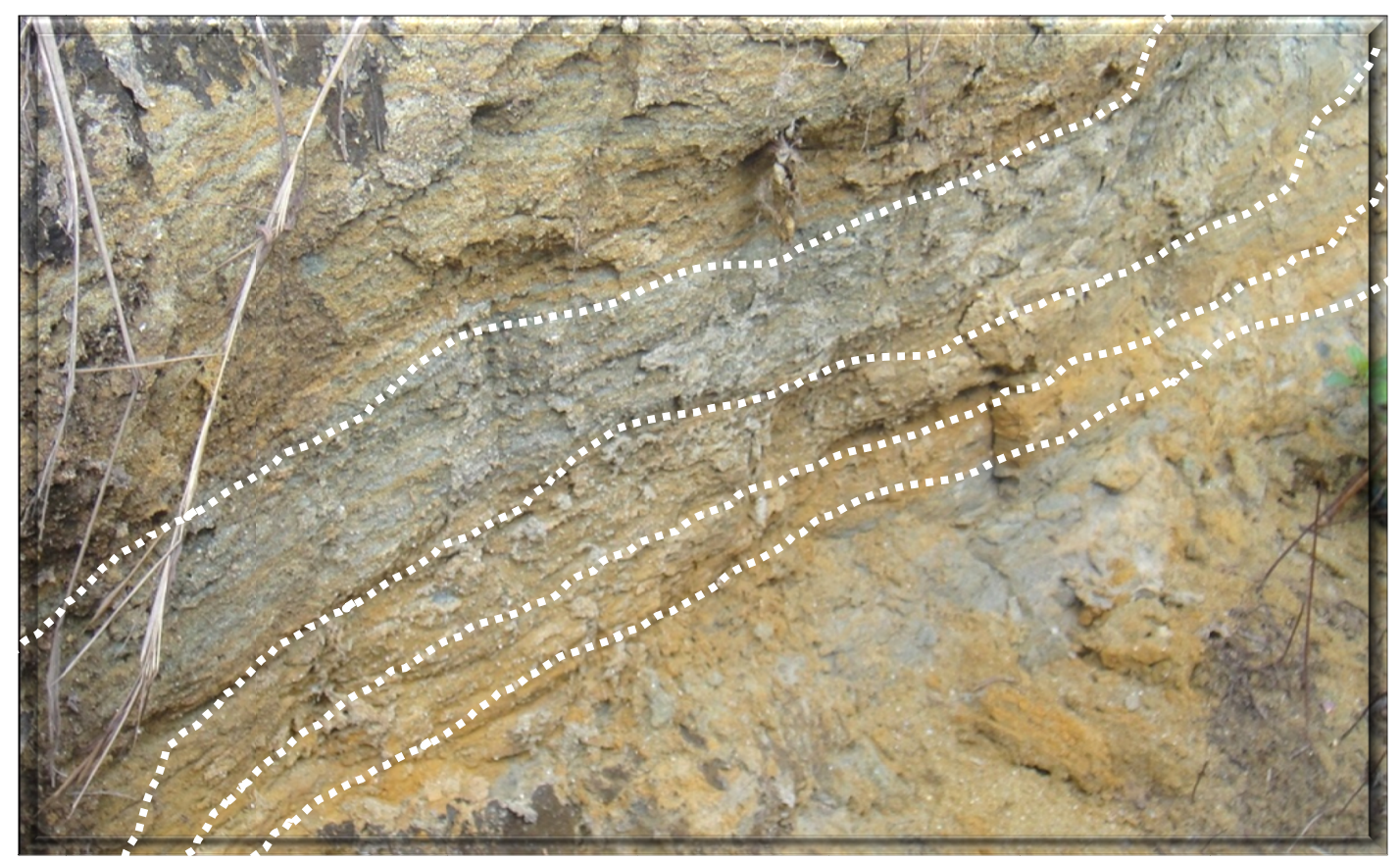

Figure 6. Ripple-laminated sandstone unit in Awi Formation

A $0.2 \mathrm{~m}$ thick grayish mudstone whose basal section is silty and micaceous overlies this unit and it shows no fissility. Above the mudstone is another sequence of deposition starting with a $0.3 \mathrm{~m}$ conglomeritic sandstone unit (Figure 7) over which a $0.35 \mathrm{~m}$ medium to fine grained sandstone unit lies and ending with a $0.45 \mathrm{~m}$ thick plastic, greenish to pinkish mudstone at the top.

The bedded units of this outcrop show a general strike in the Northwest direction $\left(285^{\circ}\right)$ and dips in the Southwest direction $\left(194^{\circ}\right)$. Field evidences indicate a fining-upward cyclic sequence at this exposure.

\section{Location 2: Along Amaseri-Okposi Road near Amaseri Crushed Stone Industry (N05'55'35.7", E007 $53^{\prime} 03.8^{\prime \prime}$ and elevation: $42 \mathrm{~m}$ )}

This location is a new quarry site along Amaseri-Okposi road. The rock exposure here is about $2.85 \mathrm{~m}$ thick (Figure 8). The basal section which is about $2.4 \mathrm{~m}$ thick comprises of light grey medium grained sandstones that are indurated, calcareous and gritty with black thin curved lines randomly distributed in them (Figure 9). The top section of this unit is slightly weathered. It is orange colored, indurated, calcareous and very gritty with grains that are mostly sub-angular to sub-round. It has a thickness of $0.45 \mathrm{~m}$.

\section{Location 3: At Ugwueme, Awgu (N06 $01^{\prime} 40.8^{\prime \prime}, E_{007}^{\circ} 28^{\prime} 14.9^{\prime \prime}$ and elevation: 215m)}

This outcrop is located on a hill. It is made up of well stratified units as well as boulders of various sizes and shapes. Rocks in this locality are weathered but still retain their sedimentary structures in sections that are indurated. The total thickness of this stratigraphic sequence derived from compositing several lithologs is about $6 \mathrm{~m}$ (Figure 10). 


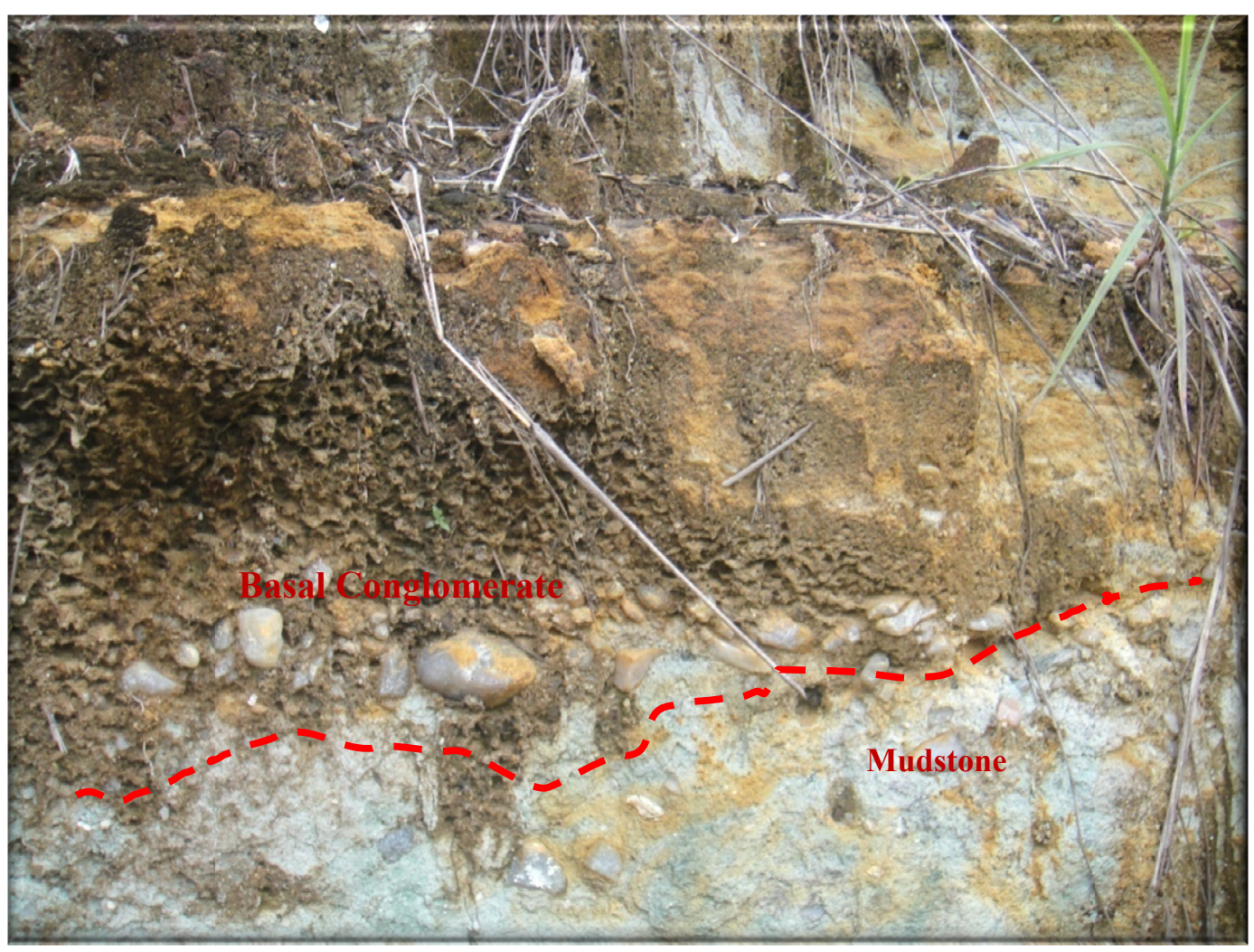

Figure 7. Conglomeritic sandstone bed of the second cycle of sedimentation in Awi Formation

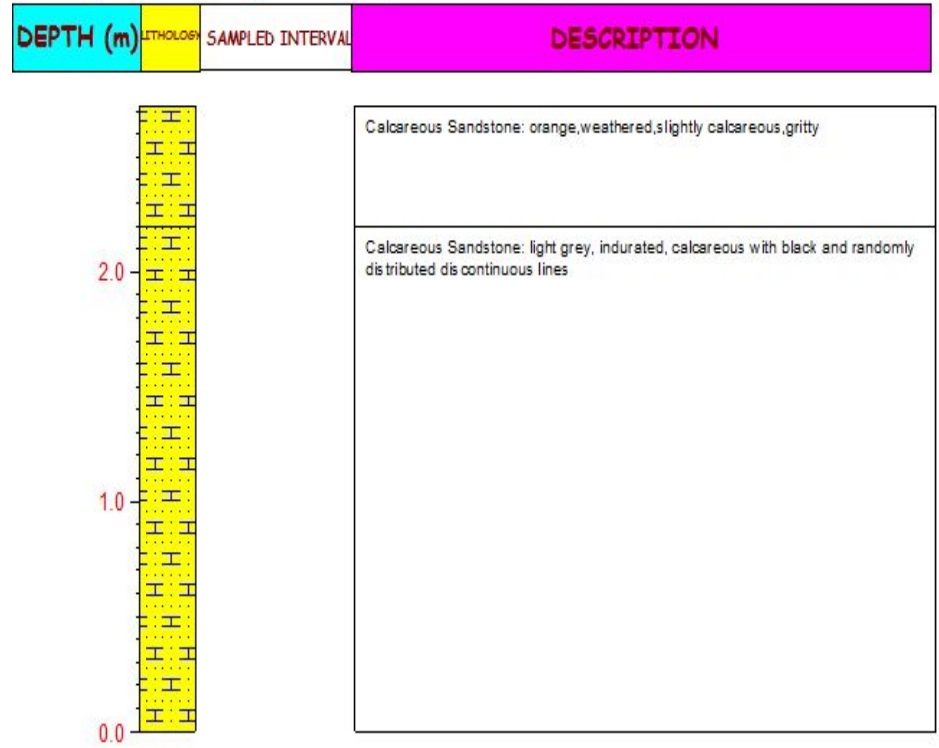

Figure 8. Log plot for Amaseri Sandstone exposure along Amaseri-Okposi road

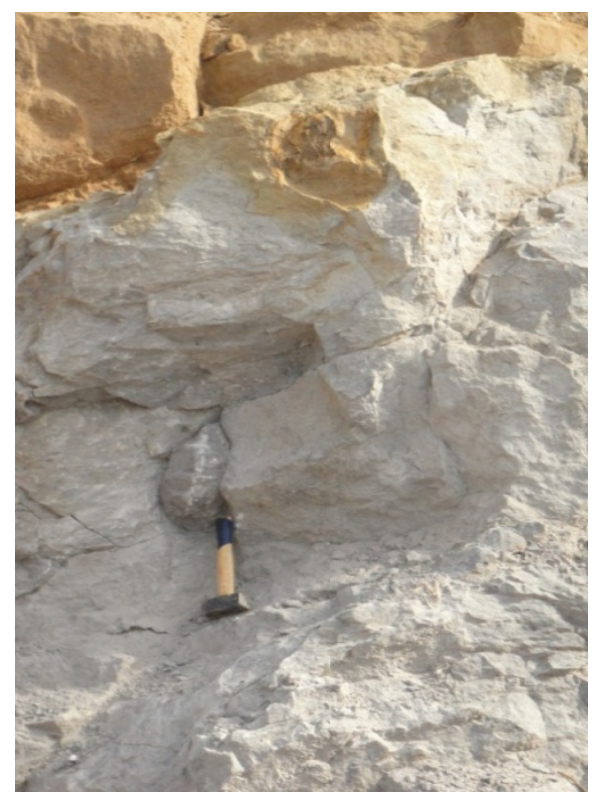

Figure 9. An exposure of Amaseri Sandstone in Amaseri Village 

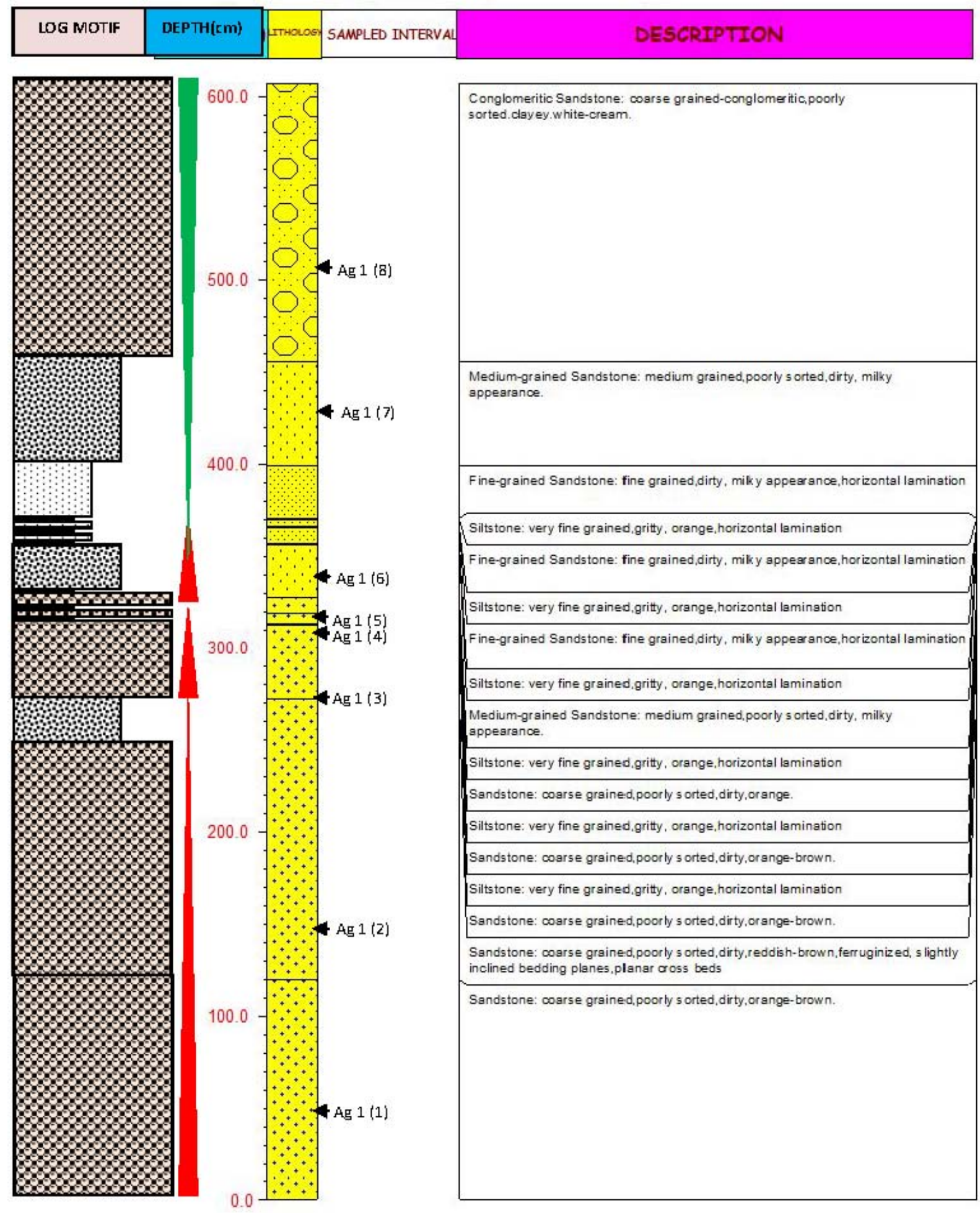

Figure 10. Log Plot for Agbani Sandstone at Ugwueme

The basal section of this outcrop is about $1.2 \mathrm{~m}$ thick, comprises of a brownish-orange, dirty, poorly sorted and coarse grained sandstone. At this base, there is oil seepage (Figure 11). 


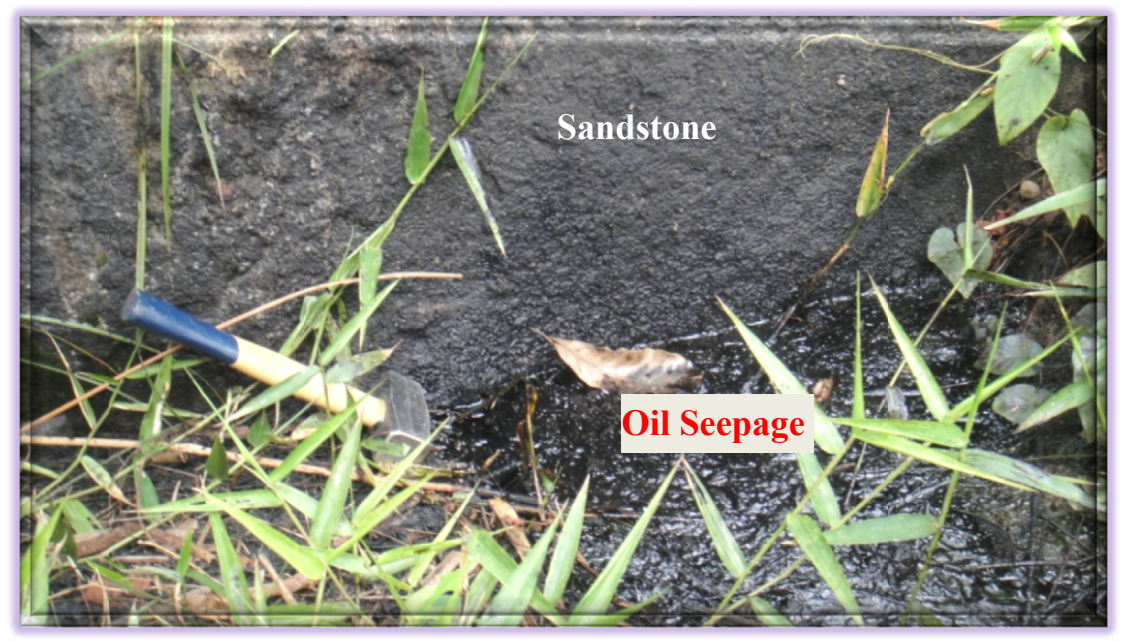

Figure 11. Oil seepage at Ugwueme (Agbani sandstone)

Overlying this unit is a reddish-brown, poorly sorted, dirty, ferruginized, and planar cross-bedded (essentially in the NS direction) coarse grained sandstone (Figure 12). The bedding planes of this sandstone unit are slightly inclined.

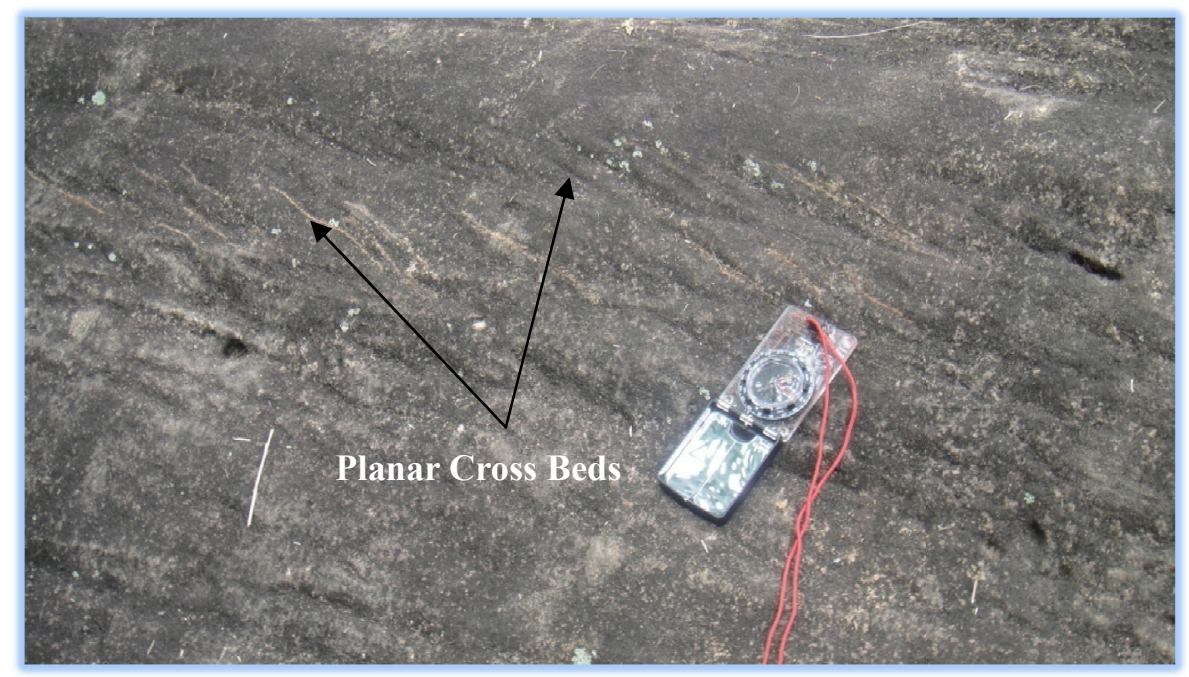

Figure 12. Planar cross beds in a sandstone unit at Ugwueme

Overlying the ferruginized sandstone unit is a sequence of sandstone and siltstone alternation with the sandstone grain size and thickness increasing upwards. While the sandstones show parallel bedding, the siltstones exhibit parallel lamination. At the top of the alternating sequence is a $1.45 \mathrm{~m}$ thick creamish-white, horizontal bedded, coarse grained to conglomeritic sandstone bed that is slightly dirty and poorly sorted. A fining and subsequent coarsing-upward sequence was observed at this location.

Location 4: At Ugwuokwute (Ugwu-nkpume), Awgu a few kilometers from Location 3 (N06 02'13.5", E007 $27^{\prime} 50.4^{\prime \prime}$, and elevation: 162)

A litholog showing the stratigraphic sequence of this location can be seen in Figure 13. It is a small quarry site for villagers living in the area. They quarry the sandstones here because of their hardness and they use them as crushed stones for building. 


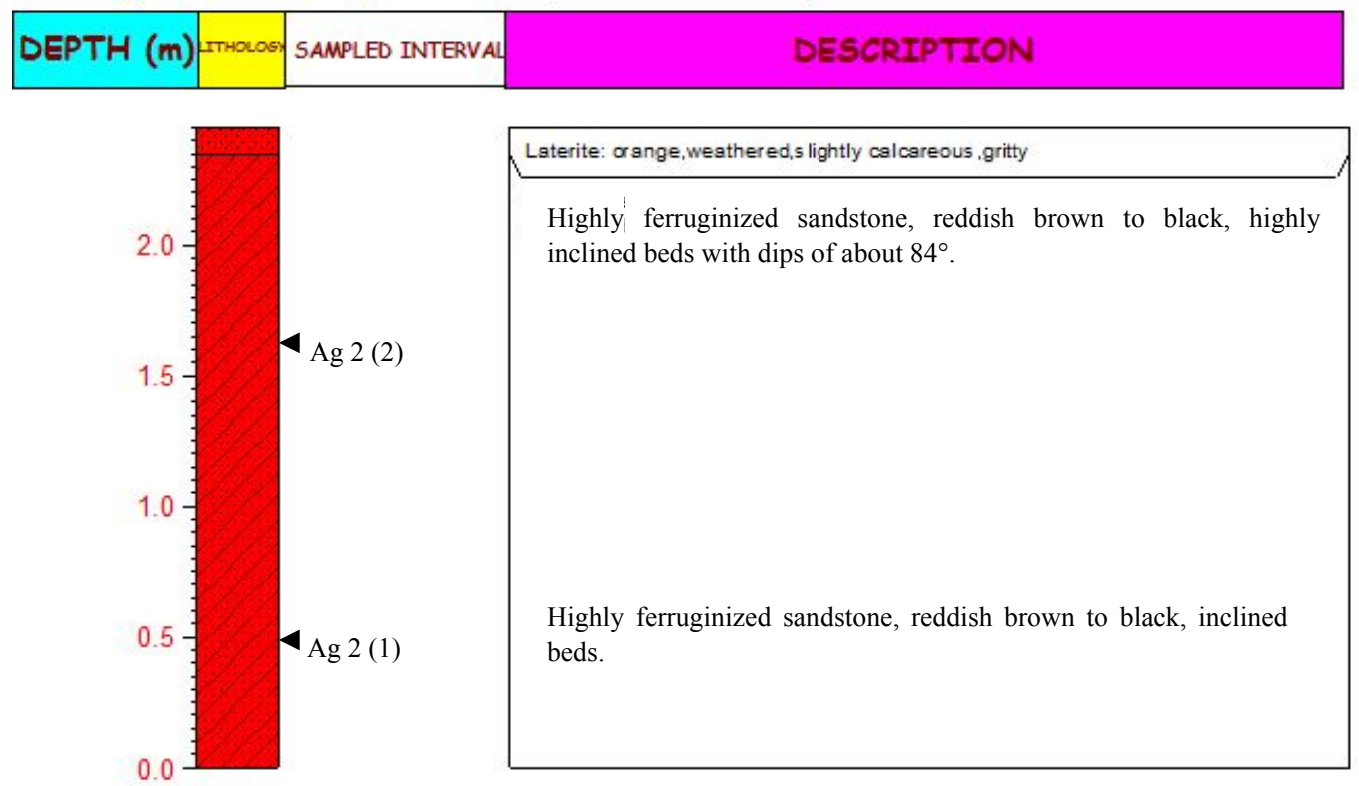

Figure 13. Log Plot for Agbani Sandstone Outcrop at Ugwuokwute

At this location, Agbani Sandstone is exposed on two faces. The first exposure is made up of a basal section that has inclined beds which strikes $188^{\circ} \mathrm{SW}$ and dips to the east and is about $1.2 \mathrm{~m}$ thick (Figure 14).

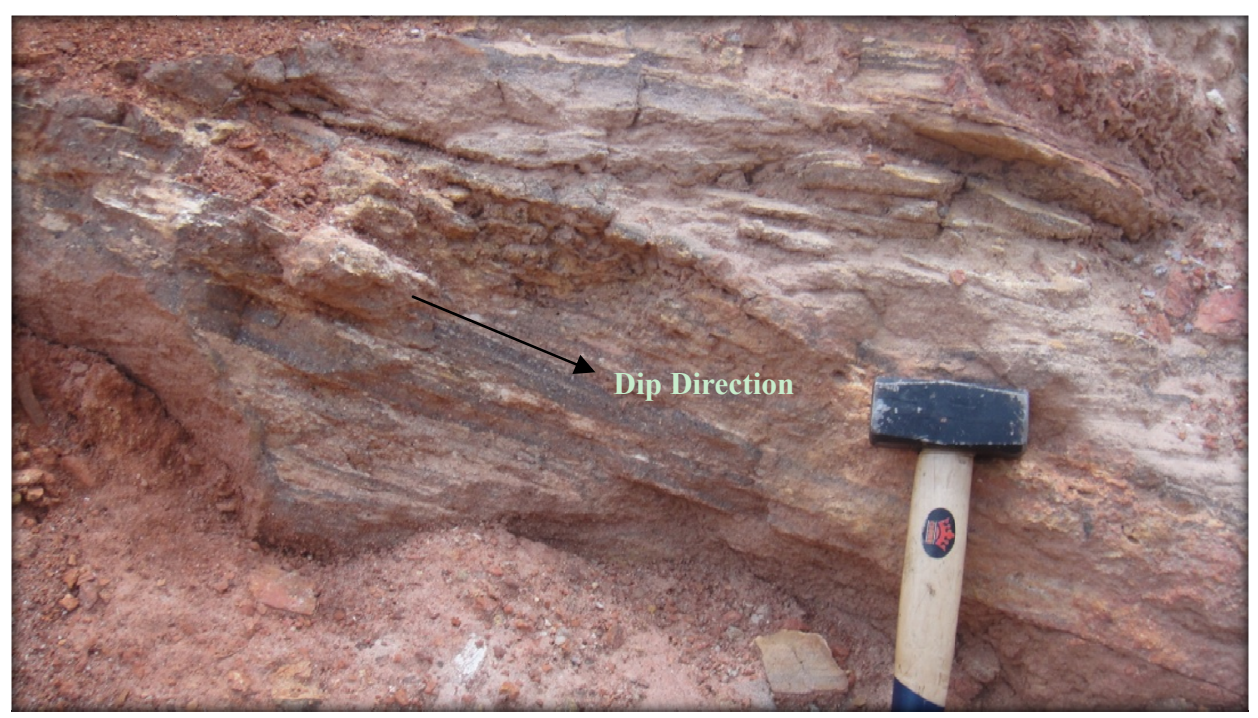

Figure 14. Inclined beds of ferruginized sandstone at Ugwuokwute

It is coarse grained, poorly sorted, indurated and highly ferruginized that it appears black with some white quartz sub-rounded to rounded grains sticking out. The upper part consists of a reddish-brown, $0.25 \mathrm{~m}$ thick laterite. The other face shows steeply inclined sandstone strata that are almost vertical (Figure 15). From left to right of the exposure, there is a grain size gradation from coarse to medium. This unit has a lateral thickness of $2.35 \mathrm{~m}$, the sandstones are poorly sorted, ferruginized, and indurated. Although inclined, the bedding surfaces appear horizontal. From field observations, the first exposure underlies the second. 


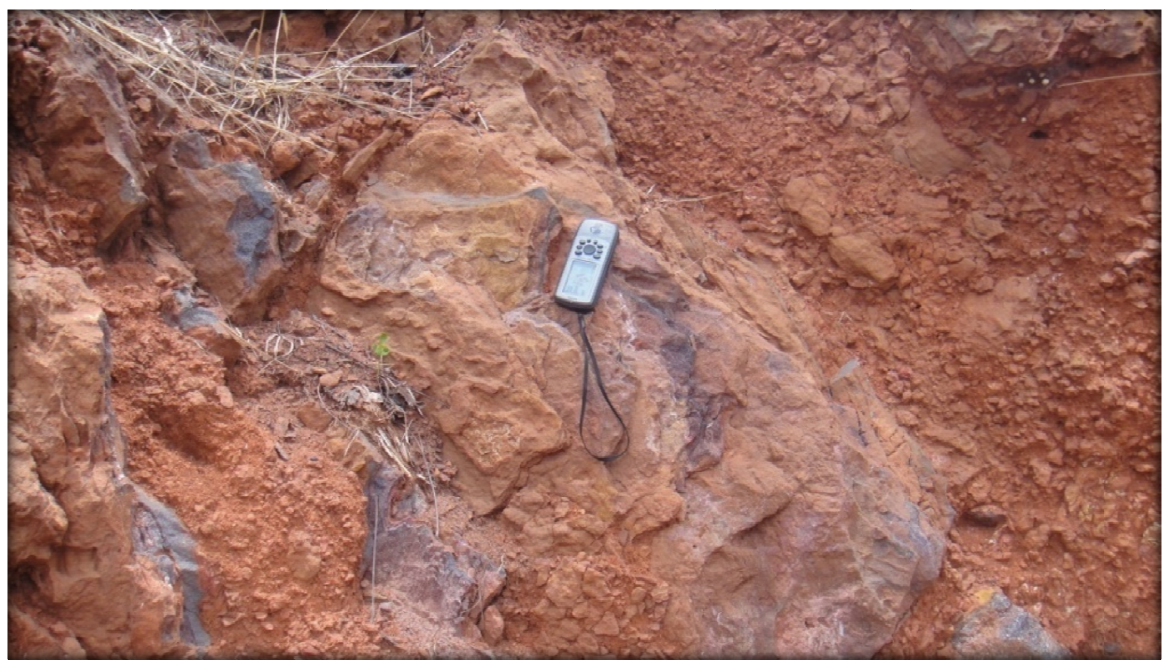

Figure 15. Steeply inclined beds of Ferruginized sandstone at Ugwuokwute, Agbani sandstone

Sedimentary structures such as planar cross beds and ripple laminations were observed in the sandstone units of the Agbani Sandstone and Awi Formation respectively. These structures according to Simons et al. (1965) reflect stream power, grain size and bedform during the time of deposition. They are established as stream power increases, larger grain fractions would be carried and planar cross beds are more likely to form in unidirectional traction systems. But with reducing stream power, ripple laminations are more likely to form. Thus, the sandstone units of Awi and Agbani are believed to be products of stream/river transporting medium with intermittent rise and fall in its flow velocity or stream power.

\subsection{Granulometric Analysis}

Cumulative $\log$ probability curves from which univariate parameters were determined show that sandstones analyzed from the Awi Formation are medium to coarse grained $(0.78-1.25 \Phi)$, poorly to moderately sorted $(0.88-1.19 \Phi)$, fine to strongly fine skewed $(0.17-0.57 \Phi)$ and ranges from mesokurtic to platykurtic $(0.76-1.19 \Phi)$ while Amaseri Sandstone is medium grained $(1.27 \Phi)$, symmetrically skewed $(0.05 \Phi)$, poorly sorted $(1.12 \Phi)$, and mesokurtic $(0.93 \Phi)$. Agbani Sandstone on the other hand, is medium to coarse-grained (0.78-1.3Ф), coarse to fine skewed $(-0.17-0.39 \Phi)$, moderately to poorly sorted $(0.87-1.03 \Phi)$, and ranges from mesokurtic to very platykurtic $(0.66-1.31 \Phi)$. Figures $16 \mathrm{a}$ and $16 \mathrm{~b}$ show the various probability curves for each formation while Table 1 shows a summary of all calculated univariate statistical parameters and their interpretations.

Table 1. A summary of calculated Univariate parameters and their interpretations

\begin{tabular}{ccccc}
\hline Sample Code & Mean size & Kurtosis & Skewness & Sorting \\
\hline Awi 3 & 1.25 & 0.76 & 0.17 & 1.19 \\
& Medium Sand & Platykurtic & Fine skewed & Poorly Sorted \\
Amaseri 2 & 1.27 & 0.93 & 0.05 & 1.18 \\
& Medium Sand & Mesokurtic & Near Symmetrical & Poorly Sorted \\
Awi 1b & 0.95 & 0.95 & 0.57 & 1.12 \\
& Coarse Sand & Mesokurtic & Strongly Fine Skewed & Poorly Sorted \\
Awi 1a & 0.93 & 0.96 & 0.48 & 1.10 \\
& Coarse Sand & Mesokurtic & Strongly Fine Skewed & Poorly Sorted \\
Awi 2 & 0.78 & 1.19 & 0.30 & 0.88 \\
& Coarse Sand & Leptokurtic & Fine Skewed & Moderately Sorted \\
Ag 1 (3) & 1.3 & 1.02 & -0.17 & 1.03 \\
& Medium Sand & Mesokurtic & Coarse Skewed & Poorly Sorted \\
Ag 1 (4) & 0.78 & 1.15 & 0.29 & 0.87 \\
& Coarse Sand & Leptokurtic & Fine Skewed & Moderately Sorted \\
Ag 1 (8) & 0.80 & 1.31 & 0.39 & 0.90 \\
& Coarse Sand & Leptokurtic & Strongly Fine Skewed & Moderately Sorted \\
Ag 1 (1) & 1.0 & 0.66 & 0.14 & 0.91 \\
& Coarse Sand & Very Platykurtic & Fine Skewed & Moderately Sorted \\
\hline
\end{tabular}


The mean size indicates the average kinetic energy (velocity) of the depositing agent (Sahu, 1964). Samples collected from the three formations, generally indicate high kinetic energy conditions of the depositing agent or medium, with a mild fluctuation to the low side accounting for the medium grain size. This is characteristic of fluvial environments. It is generally considered that sediments are usually more poorly sorted when they are closer to their source (provenance) and that mean size and sorting are hydraulically controlled so that in all environments, the finer the grain size, the better the sorting. This indicate that Awi Formation and Amaseri Sandstone are closer to their sources and haven't traveled very far, while samples from Agbani Sandstone indicate a relatively longer time of travel from their source (relatively farther from provenance).

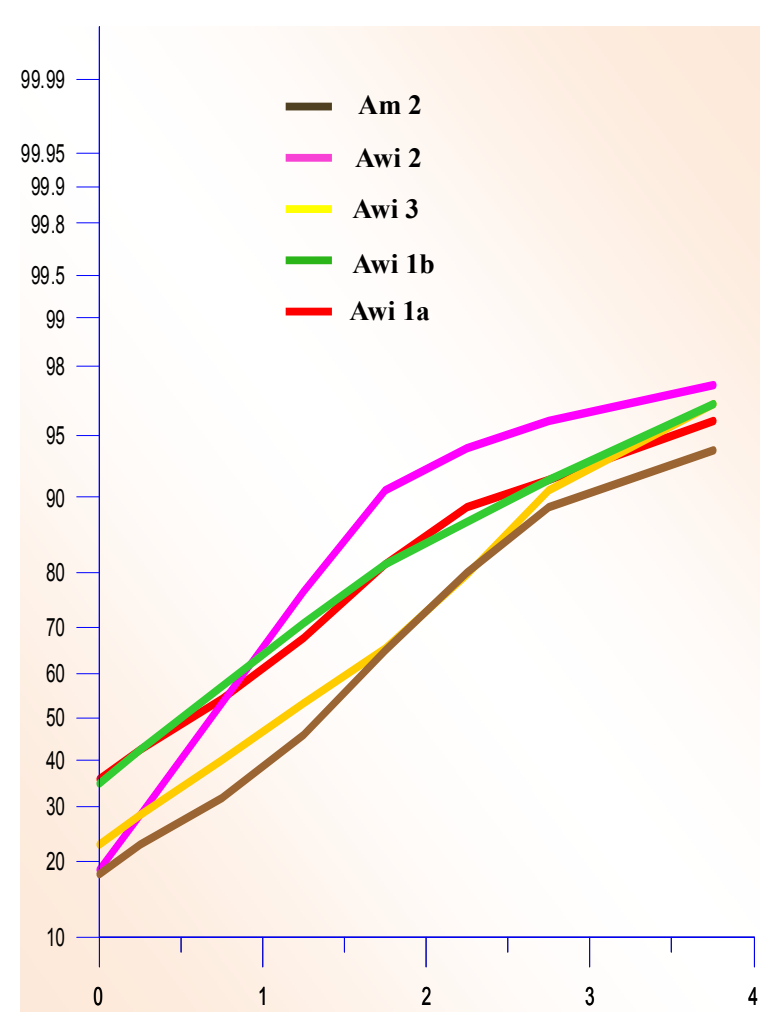

(a)

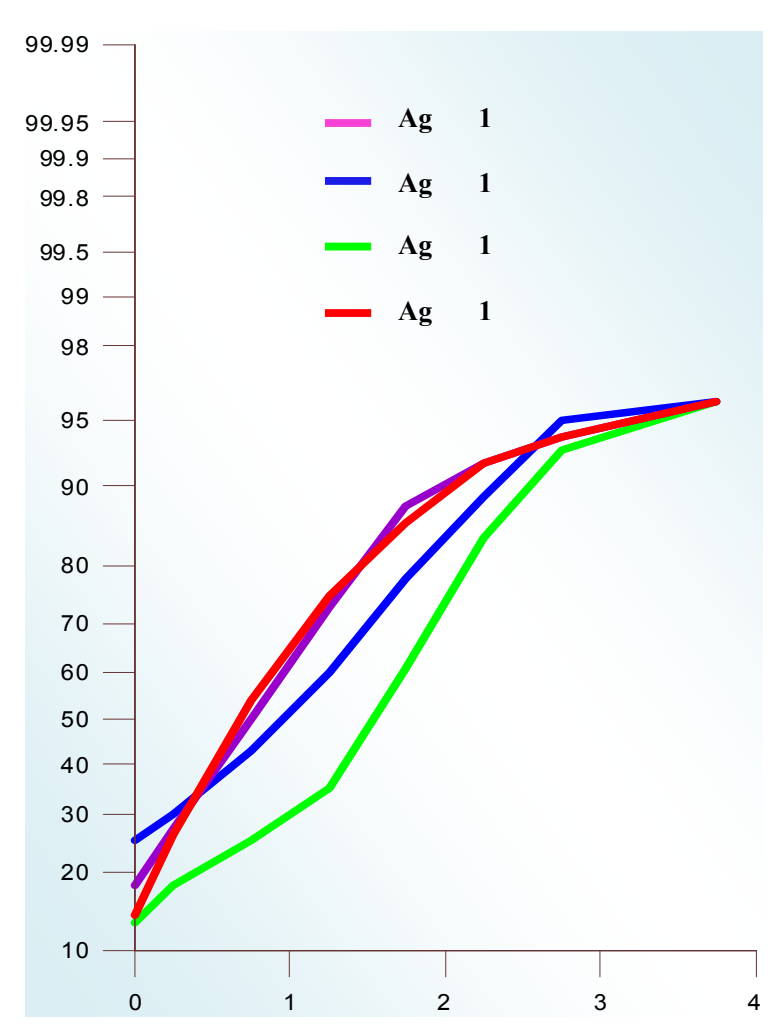

(b)

Figure 16. (a) Log probability plots for Awi Formation and Amaseri sandstone (Am); (b) Log probability plots for Agbani sandstone (Ag)

The poorly-moderately sorted nature of the sediments reflects an increased to moderate fluctuation of energy conditions of the depositional medium and hence, a very poor-moderate winnowing ability. Moreso, curves with excess fine material (a tail to the right) indicate coarse skewness and those with excess coarse material (a tail to the left) have fine to strongly fine skewness. Since the deposition of sediments is governed by the energy conditions of the transporting medium, a sudden drop in the energy of the depositing medium will cause the deposition of a higher percentage of sediments, coarser than the median size, thus making the sediments of the river fine to strongly fine skewed (Awasthi, 1970) as is seen in both Awi Formation and Agbani Sandstone. A gradual decrease in the energy of the depositional medium also causes the deposition of much finer grains. This condition therefore accounts for the near symmetrical nature of the sample representing Amaseri Sandstone (Figure 17e).

Frequency curves and histograms (Figure 17) for Awi Formation show a strong unimodal character for the basal units and a weak bimodal character for the overlying units. The only sample analyzed from Amaseri is of strong bimodal character, while three samples representing Agbani Sandstone display a strong unimodal character and one sample showing a bimodal pattern. 


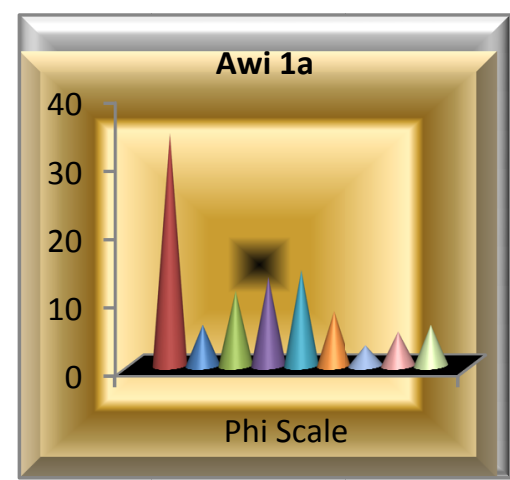

(a)

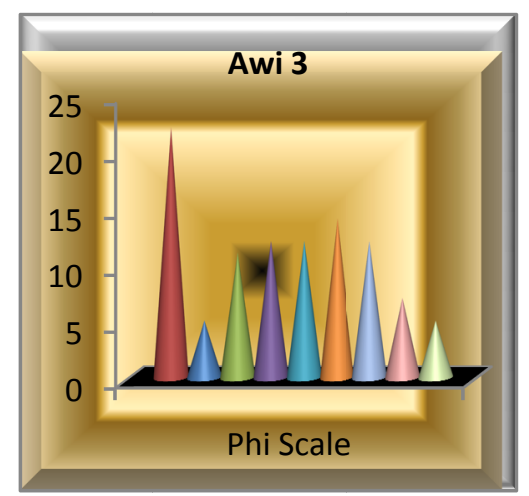

(d)

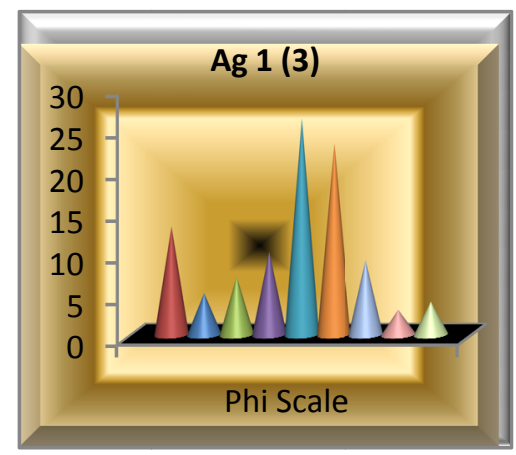

(g)

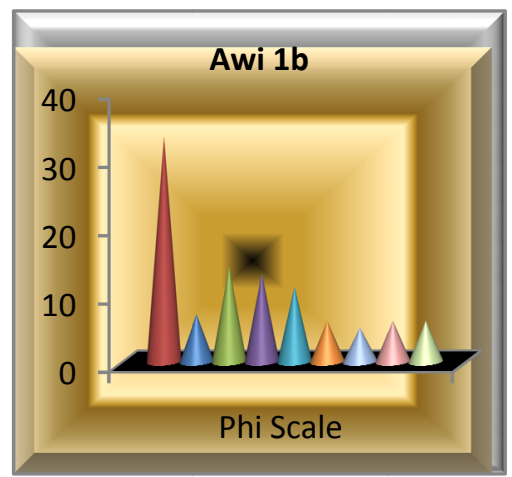

(b)

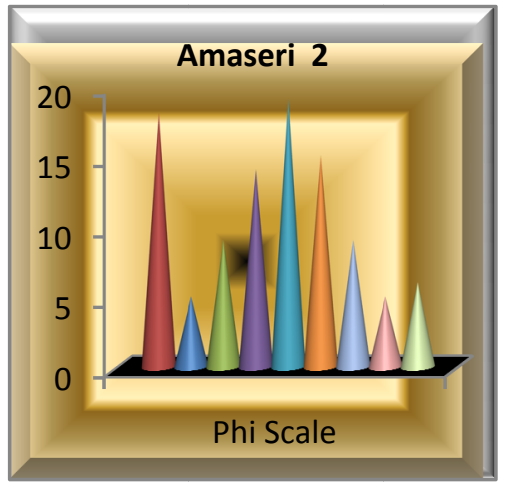

(e)

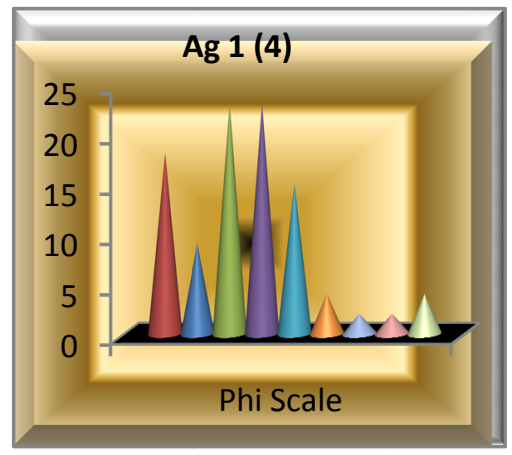

(h)

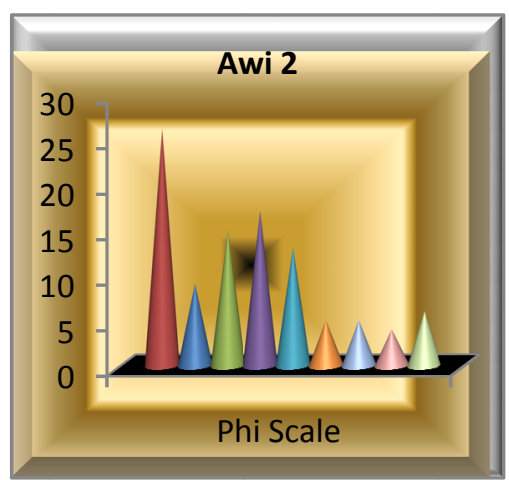

(c)

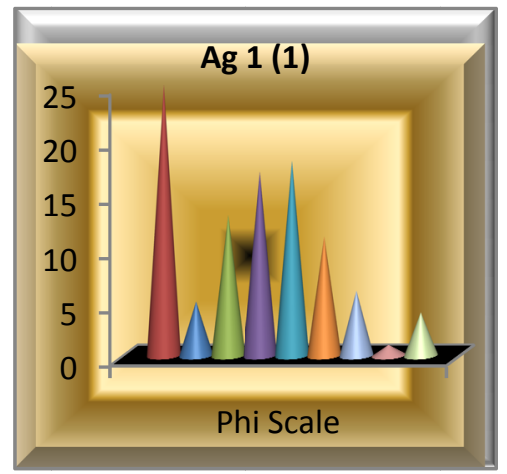

(f)

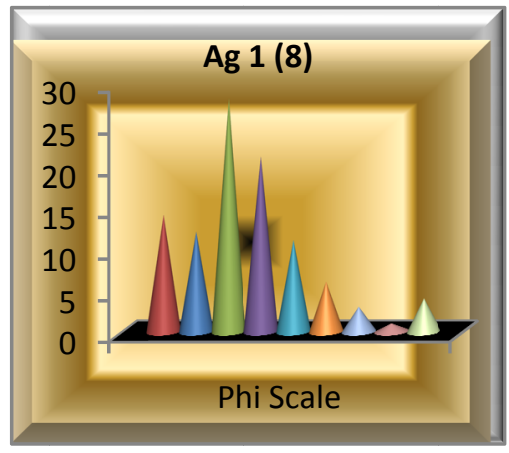

(i)

Figure 17. Histograms for samples of the studied area

Bivariate plot of grain size data based on Friedman (1967) show that all samples analyzed are fluvial deposits (Figure 18). Multivariate analyses to discriminate between shallow marine and fluvial processes show that sandstones of the Awi Formation, Amaseri and Agbani Sandstones are fluvial deposits. 


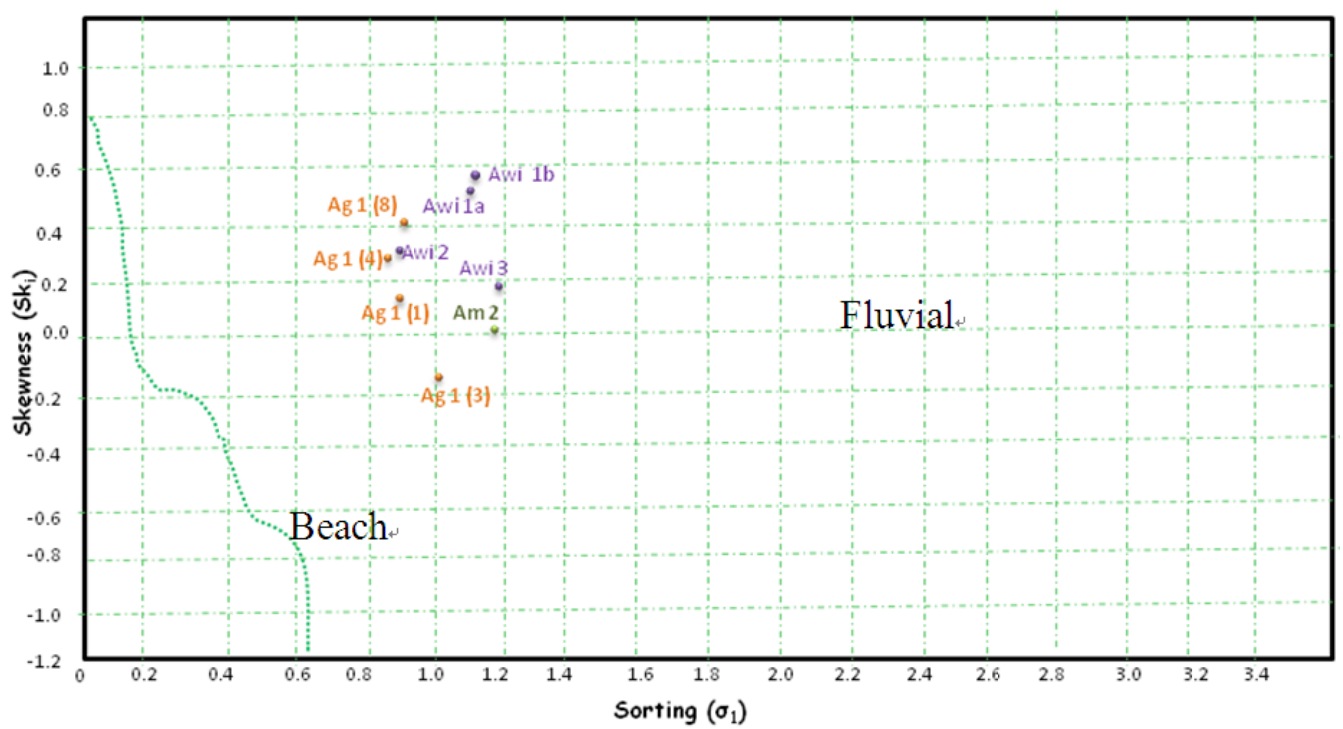

Figure 18. Bivariate plot of skewness against sorting (After Friedman, 1961)

Table 2. Multivariate results for all samples analyzed based on Sahu (1964) using shallow marine versus fluvial discriminant

\begin{tabular}{ccc}
\hline Sample & Results & Interpretation \\
\hline Ag 1 (8) & -9.50145 & Fluvial \\
Ag 1 (4) & -8.76273 & Fluvial \\
Ag 1 (3) & -7.7715 & Fluvial \\
Ag 1 (1) & -8.34005 & Fluvial \\
Am 2 & -10.175 & Fluvial \\
Awi 3 & -10.8636 & Fluvial \\
Awi 2 & -8.89734 & Fluvial \\
Awi 1b & -12.2841 & Fluvial \\
Awi 1a & -11.6737 & Fluvial \\
\hline
\end{tabular}

The unimodal pattern from the plots of Rose diagram of Agbani Sandstone for palaeocurrent pattern indicate fluvial depositional systems (Figure 19).

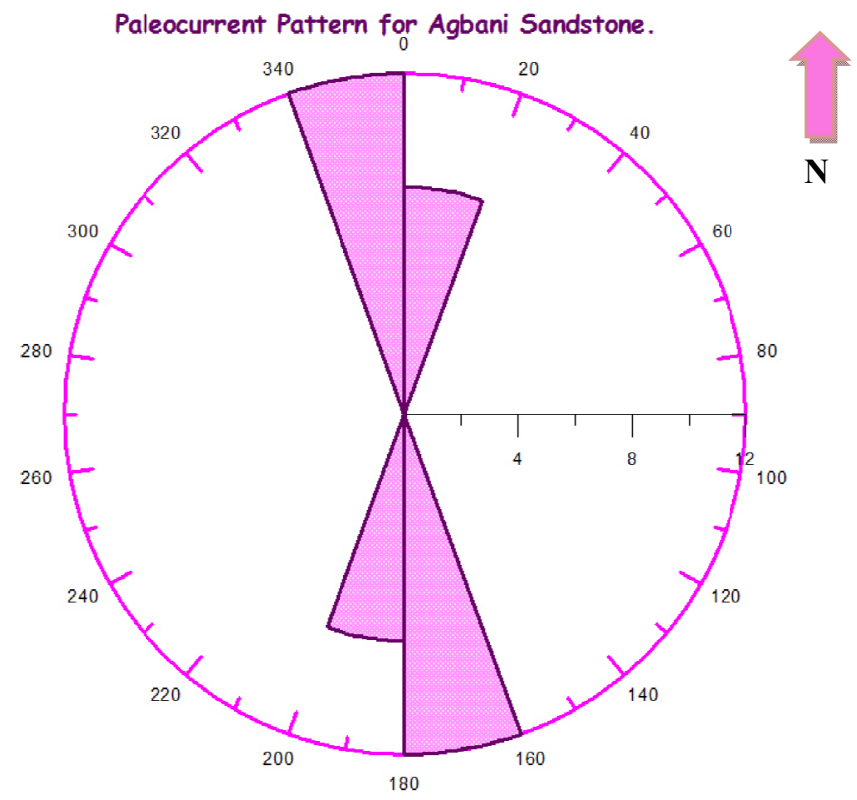

Figure 19. Rose diagram showing paleocurrent pattern for Agbani Sandstone 


\subsection{Thin Section Petrography}

The compositional framework of all the samples subjected to thin section study is summarized in Table 3 . From the table, it can be seen that for all formations, both metamorphic and plutonic (common) quartz (Figure 20) are present in varying proportions and ratios.

Table 3. Petrographic analysis data

\begin{tabular}{lllllllllllllllll}
\hline $\begin{array}{l}\text { Framework } \\
\text { Components }\end{array}$ & Aw1 & Aw2 & Aw3 & Am 1 & Am2 & $\begin{array}{l}\text { Ag1 } \\
(1)\end{array}$ & $\begin{array}{l}\text { Ag1 } \\
(2)\end{array}$ & $\begin{array}{l}\text { Ag1 } \\
(3)\end{array}$ & $\begin{array}{l}\text { Ag1 } \\
(4)\end{array}$ & $\begin{array}{l}\text { Ag1 } \\
(5)\end{array}$ & $\begin{array}{l}\text { Ag1 } \\
(6)\end{array}$ & $\begin{array}{l}\text { Ag1 } \\
(7)\end{array}$ & $\begin{array}{l}\text { Ag1 } \\
(8)\end{array}$ & $\begin{array}{l}\text { Ag2 } \\
\text { Qg3 } 3 \\
(1)\end{array}$ & $\begin{array}{l}\text { Ag3 } \\
(2)\end{array}$ \\
\hline Quartz & 70 & 77 & 73 & 72 & 76 & 76 & 77 & 73 & 79 & 70 & 71 & 70 & 82 & 66 & 79 & 75 \\
Feldspar & 11 & 7 & 11 & 4 & 4 & 10 & 2 & 4 & 3 & 8 & 9 & 7 & 2 & 12 & 2 & 1 \\
Mick Fragment & 2 & 3 & 3 & 10 & 6 & 2 & 1 & 9 & 1 & 3 & 3 & 4 & 1 & 2 & 2 & 2 \\
Heavy Mineral & 1 & - & 1 & 2 & 3 & 2 & - & 1 & 1 & 1 & 3 & 2 & 2 & 1 & - & 1 \\
MQ:PQ & $1: 3$ & $1: 1$ & $2: 1$ & $1: 3$ & $1: 2$ & $2: 3$ & $3: 2$ & $1: 3$ & $1: 3$ & $2: 1$ & $2: 1$ & $2: 3$ & $2: 3$ & $1: 2$ & $1: 3$ & $1: 3$ \\
Plutonic Quartz & 4.5 & 32.1 & 26.3 & 12 & 8.2 & 8.6 & 27.4 & 4.7 & 12.8 & 9.2 & 39.5 & 18 & 24.6 & 8 & 14.4 & 16.6 \\
Vein Quartz & 13 & 6.3 & 22.4 & 6 & 15.1 & 21.8 & 18.2 & 13.6 & 7 & 37.5 & 7.8 & 10 & 8.2 & 14.2 & 5.4 & 2.1 \\
SMQ & 38.2 & 18.5 & 10 & 42.6 & 43.6 & 39 & 26.2 & 51 & 43.5 & 15.6 & 19 & 31 & 40.1 & 35.7 & 50.2 & 44.2 \\
RMQ & 14 & 7.2 & 14.3 & 11.4 & 7 & 6.6 & 4.2 & 3.7 & 15.7 & 7.7 & 4.7 & 11 & 9.1 & 8.3 & 9 & 12.1 \\
Matrix & 3 & 4.5 & 8 & 4 & 6 & 8 & 5 & 7 & 2 & 10 & 2 & 10 & 3 & 7 & 1 & 2 \\
Cement & 5 & 7.5 & 4 & 7 & 5 & 2 & 13 & 4 & 14 & 6 & 12 & 6 & 10 & 7 & 16 & 20 \\
\hline
\end{tabular}

SMQ: Stretched Metamorphic Quartz, RMQ: Recrystallized Metamorphic Quartz, MQ: Monocrystalline Quartz, PQ: Polycrystalline Quartz.

According to the classification scheme of Folk (1968), sandstones from Awi Formation are subarkosic arenites, while those representing Amaseri Sandstone are sublitharenites. Agbani Sandstone comprises of both quartz arenites and subarkosic arenites with a minor occurrence of sublitharenite. Samples from Awi Formation have total quartz ranging from 70 to $77 \%$, while those from Amaseri and Agbani Sandstones range from 72 to $76 \%$ and 66 to $82 \%$ respectively. Computed averages are $73.3 \%, 74 \%$, and $74.4 \%$ respectively. These quartz grains are predominantly angular to subangular with a few subrounded to rounded grains. While the monocrystalline grains show dominantly straight extinction with point to point (tangential) contacts, the polycrystalline grains contain 2 to 10 crystals with similar sizes and show a moderate to strongly undulose extinction with sutured grain contacts. The ratio of monocrystalline to polycrystalline quartz for all samples is also shown in Table 3 . Feldspars from Awi are both sodic and potassic (albite and microcline), with some degree of alteration and range from 7 to $11 \%$, that of Amaseri Sandstone, range from 3 to $4 \%$ and include albite and orthoclase, while the feldspar from Agbani Sandstone are basically plagioclase and orthoclase it range from 1 to $12 \%$. The average values are $9.7 \%, 4 \%$, and $5.45 \%$ respectively. The ranges and averages for rock fragments in the formations studied are as follows: Awi Formation, 2-3\%; (2.7\%), Amaseri Sandstone, 6-10\%; (8\%), and Agbani Sandstone, $1-9 \% ;(2.7 \%)$. Both muscovite and biotite are present in very minute amounts and non-opaque heavy minerals such as zircon and tourmaline could be identified.

Matrix is present in all samples studied averaging 5.2\% for Awi Formation, 6.8\% for Amaseri Sandstone, and 5.5\% for Agbani Sandstone. Constituents of these matrices include clay minerals, quartz and silt size feldspars (Figure 20). Cement constitutes a significant fraction for some samples (especially those from Agbani Sandstone). It ranges from 4-7.5\% for Awi Formation, 4-5\% for Amaseri Sandstone, and 2-20\% for Agbani Sandstone. Iron oxide, silica (quartz) and calcite were the three cement types identified.

Using the classification scheme of Folk (1974) for textural maturity, samples from Awi Formation and Amaseri Sandstone range from texturally immature to submature while those of Agbani Sandstone range from texturally immature to mature. Based on compositional maturity classification which involves the use of the ratio of quartz to that of feldspar and rock fragment put together, the compositional maturity of the sand bodies of Awi Formation and Amaseri Sandstone is submature. Although most of the samples from Agbani Sandstone are compositionally submature, a few are supermature.

\subsection{Heavy Mineral Analysis}

Results from the 16 samples studied revealed variable amounts of opaque's (magnetite and hematite), ultrastable (Zircon, Tourmaline, Rutile), stable (Apatite, Garnet, Staurolite), moderately stable (Zoisite, Kyanite, Sillimanite) and Hornblende, Topaz, Spinel (Hercynite), and Muscovite. The ultrastable minerals are dominant in all formations but tourmaline appears to be the most abundant (Figure 21).

The most peculiar characteristics of these heavy minerals are as follows (Figure 21). 

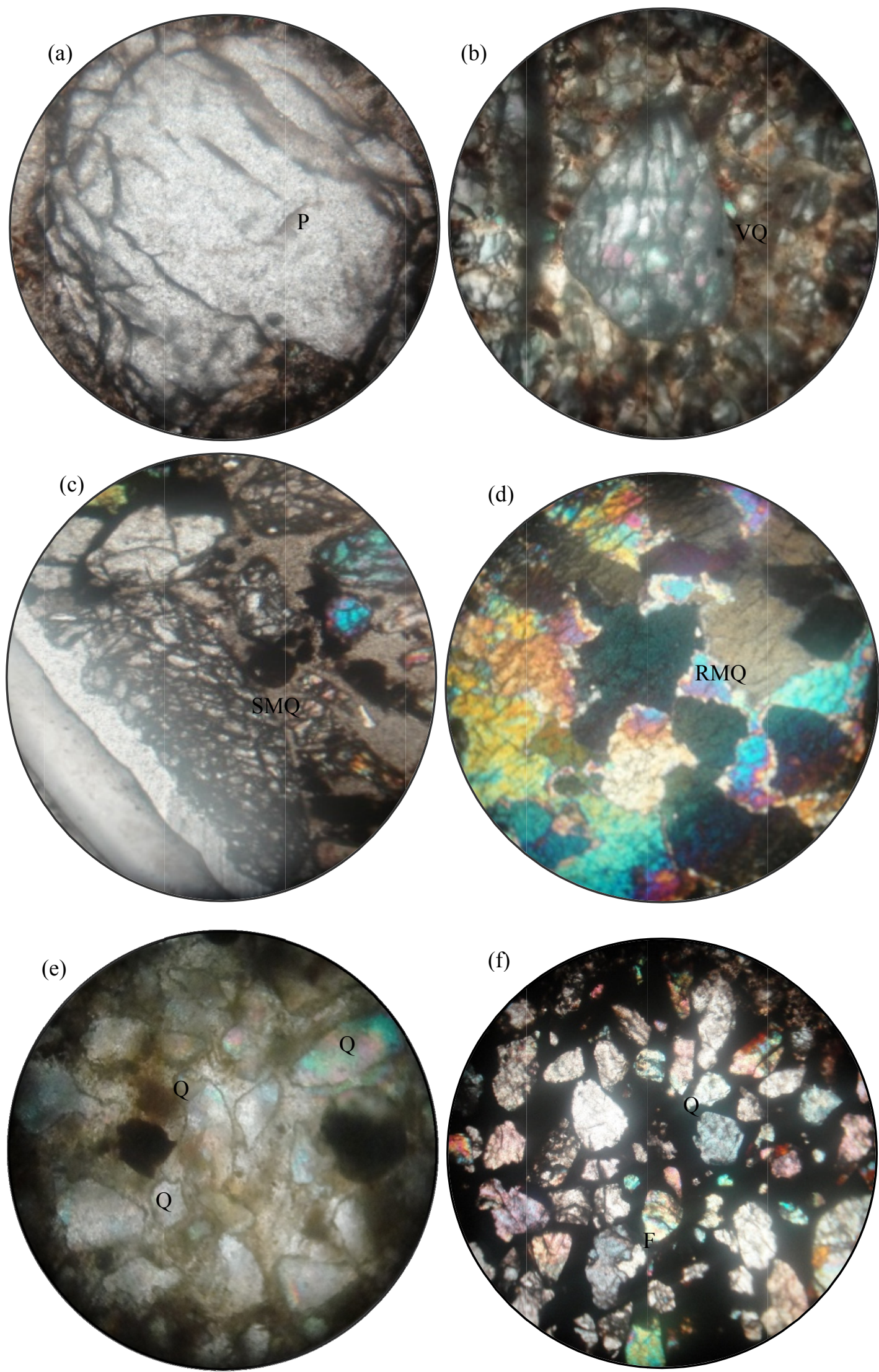

Figure 20. (a) Plutonic Quartz (PQ); (b) Vein Quartz (VQ); (c) Stretched Metamorphic Quartz (SMQ); (d) Recrystallized Metamorphic Quartz (RMQ); (e) Subangular to Subround Grains in a Quartz Arenite; (f) Poorly Sorted Arkosic Arenite 


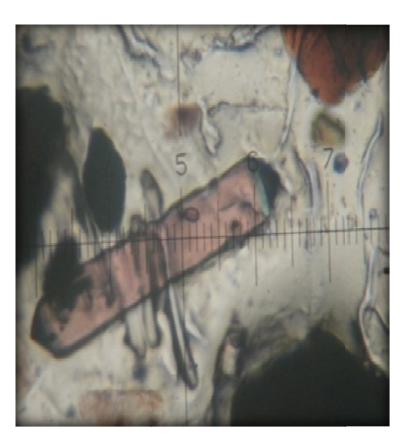

(A)

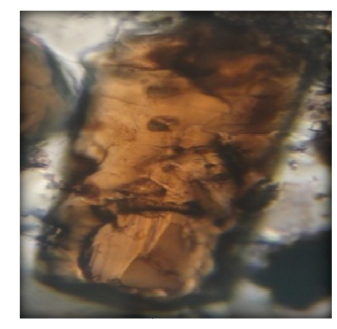

(E)

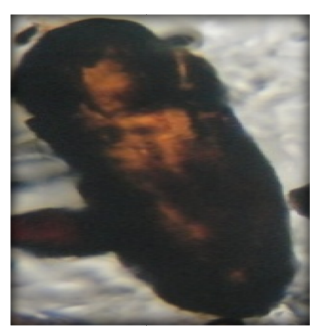

(J)

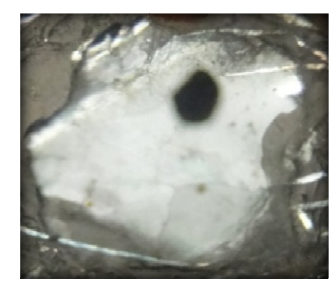

(O)

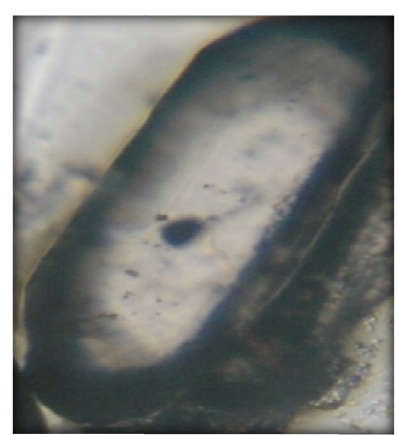

(B)

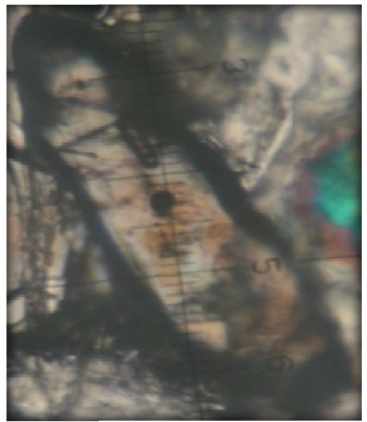

(C)

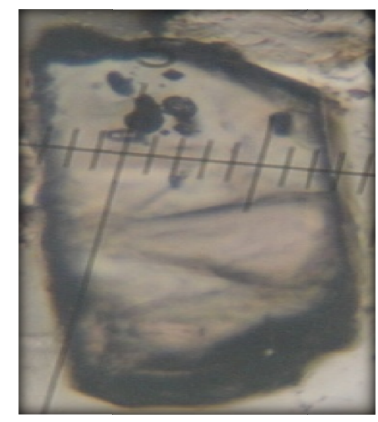

(D)

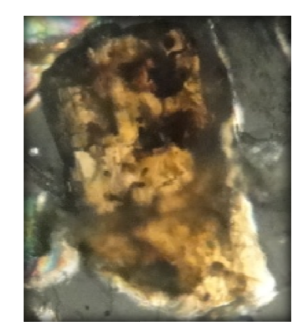

(H)

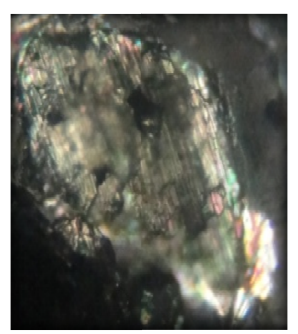

(M)

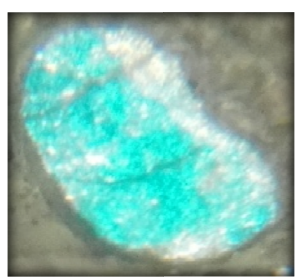

(R)

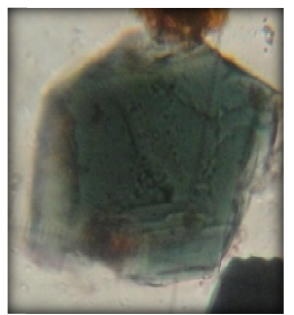

(I)

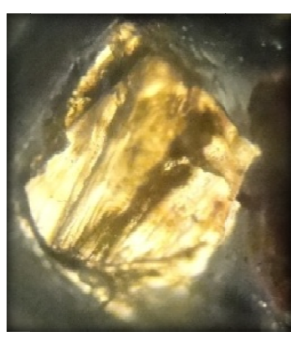

(N)

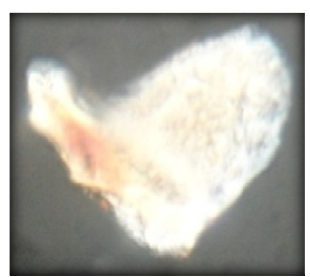

(S)

A-D: Zircon (x10); E-I: Tourmaline (x10); J: Rutile (x10); K: Hornblende (x10); L-M: Sillimanite (x10); N: Staurolite (x10); O: Muscovite (x10); P: Spinel (Hercynite) x10; Q: Kyanite (x10); R: Zoisite (x60); S: Topaz (x10)

Figure 21. Heavy mineral species identified in Awi Formation, Amaseri and Agbani Sandstones 
Table 4. Data presentation for heavy mineral identified in samples collected from Awi, Amaseri and Agbani Sandstones

\begin{tabular}{|c|c|c|c|c|c|c|c|c|c|c|c|c|c|c|c|c|c|c|c|c|}
\hline 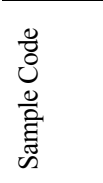 & 总 & 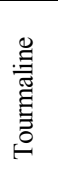 & $\stackrel{0}{\stackrel{\Xi}{2}}$ & 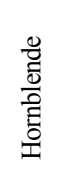 & 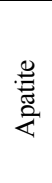 & 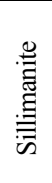 & 芯 & 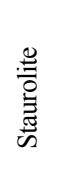 & है & $\begin{array}{l}\text { 宸 } \\
\text { 齐 }\end{array}$ & $\begin{array}{l}\bar{\Xi} \\
\text { के }\end{array}$ & : & 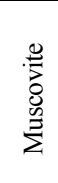 & $\begin{array}{l}\dddot{g} \\
\stackrel{\Xi}{0} \\
\tilde{\sigma}\end{array}$ & 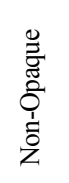 & 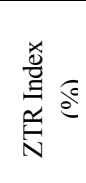 & $\begin{array}{l}\mathrm{Z} \\
\%\end{array}$ & $\begin{array}{c}\mathrm{T} \\
\%\end{array}$ & $\begin{array}{l}\mathrm{R} \\
\%\end{array}$ & $\begin{array}{c}\text { Total } \\
\text { Grains }\end{array}$ \\
\hline$\overline{\mathrm{Ag}} 4$ (2) & 18 & 23 & 7 & 1 & 2 & - & 1 & 4 & - & - & - & - & - & 28 & 56 & 85.7 & 37.5 & 47.9 & 14.5 & 84 \\
\hline $\operatorname{Ag} 4$ (1) & 5 & 9 & 3 & - & - & - & - & 1 & - & - & - & - & - & 56 & 18 & 94.4 & 29.4 & 52.9 & 17.6 & 74 \\
\hline $\operatorname{Ag} 2$ & 12 & 10 & 6 & - & - & - & 1 & 2 & - & - & - & - & 1 & 51 & 32 & 90.3 & 42.9 & 35.7 & 21.4 & 82 \\
\hline $\operatorname{Ag} 1(8)$ & 7 & 15 & 3 & 2 & 3 & - & - & - & - & - & - & - & - & 36 & 30 & 83.3 & 28 & 60.0 & 12 & 66 \\
\hline $\operatorname{Ag} 1$ (7) & 7 & 10 & 4 & - & 1 & - & - & 2 & - & - & - & - & 2 & 60 & 24 & 87.5 & 33.3 & 47.6 & 19 & 84 \\
\hline $\operatorname{Ag} 1$ (6) & 4 & 9 & 2 & - & - & - & 1 & - & - & - & - & - & - & 28 & 16 & 93.8 & 26.7 & 60 & 13.3 & 44 \\
\hline $\operatorname{Ag} 1$ (5) & 10 & 17 & 8 & 1 & - & - & - & 3 & - & - & - & - & - & 143 & 39 & 89.7 & 28.6 & 48.6 & 22.9 & 182 \\
\hline $\operatorname{Ag} 1$ (4) & 4 & 11 & 3 & 1 & - & - & 1 & 1 & - & 1 & 1 & - & - & 75 & 23 & 78.3 & 22.2 & 61.1 & 16.7 & 95 \\
\hline $\operatorname{Ag} 1$ (3) & 5 & 10 & 4 & 1 & 1 & - & 1 & - & - & - & - & - & - & 62 & 22 & 86.4 & 26.3 & 52.6 & 21.1 & 84 \\
\hline $\operatorname{Ag} 1$ (2) & 6 & 10 & 4 & 1 & - & 1 & 2 & 3 & - & - & - & - & 1 & 86 & 27 & 74.1 & 23.1 & 38.46 & 15.38 & 112 \\
\hline $\mathrm{Ag} 1$ (1) & 28 & 7 & 5 & 3 & 3 & 2 & 2 & - & - & - & - & - & - & 95 & 50 & 80.0 & 70.0 & 17.5 & 12.5 & 145 \\
\hline Am2 & 9 & 41 & 3 & 1 & 2 & 1 & 2 & 1 & 2 & - & - & - & - & 34 & 62 & 85.5 & 17.0 & 77.4 & 5.6 & 96 \\
\hline Am 1 & 8 & 10 & 6 & 2 & - & 1 & 2 & 1 & - & - & - & - & - & 64 & 30 & 80.0 & 33.3 & 41.7 & 25 & 94 \\
\hline Awi 3 & 5 & 17 & 4 & 1 & 2 & - & - & - & - & - & - & 1 & 4 & 175 & 30 & 86.7 & 19.2 & 65.4 & 15.4 & 204 \\
\hline Awi 2 & 7 & 25 & 3 & 1 & - & 2 & 1 & - & 3 & - & - & - & 8 & 25 & 42 & 83.3 & 20.0 & 71.4 & 8.57 & 67 \\
\hline Awi 1 & 6 & 13 & 6 & 3 & - & - & 2 & 2 & - & 1 & - & - & 2 & 57 & 33 & 75.8 & 24.0 & 52.0 & 24.0 & 89 \\
\hline
\end{tabular}

The ZTR ternary plots of Hubert (1962) is shown in Figure 26 and shows the collective plots of recalculated zircon, tourmaline and rutile abundances. ZTR indices for studied samples range from $75.8-86.7 \%$ (Awi Formation), $80-85.5 \%$ (Amaseri Sandstone) and 74.1-94.4\% (Agbani Sandstone). The above indices are indicative of mature to supermature sandstones.

\subsection{Discussion}

Provenance interpretations for the samples studied encompasses the use of both their textural characteristics and mineralogical compositions, which of course, reflect their source rock composition, climatic, as well as tectonic settings.

\subsubsection{Depositional Environments}

Characteristics grain size distributions are governed largely by processes within the depositional environment (Cheel, 2005) and as such, properties like mean size, sorting, skewness and kurtosis, would cumulatively reflect these processes and provide a basis for interpreting ancient depositional environments. With that in mind, high energy conditions are thus considered to have prevailed dominantly during the deposition of the basal sand units of the Awi Formation but abruptly dropped during the deposition of the upper sand units. This energy drop is visible in the log motif of the Awi Formation which shows a fining-upward sequence (Figure 4). The drop in the velocity of the transporting medium stabilized during the deposition of the Amaseri Sandstone and at the lower units of the Agbani Sandstone, although further upwards on the stratigraphic sequence of the Agbani Sandstone, there are intermittent fluctuations between high and moderate energy conditions which is reflected by frequent increase and decrease in grain size as well as the degree of sorting. This is also visible in the log motif of the section where the samples were collected (initial fining-upward to subsequent coarsening upward) (Figure 10). Fining-upward sequences with basal lag (conglomeritic) within a single sand body as is the case for Awi Formation, implies a waning-current sequence, an upward decrease in fluid velocity within a channel, and typically characterizes meandering or tidal channels, alluvial point bars or deltaic distributaries (Catuneanu, 2002). But the cyclicity of this sequence in a single outcrop points to a play between rise and fall of eustatic sea level and basin subsidence at a local level and within a short period of time. The initial fining-upwards of the sandstone units of Agbani Sandstone would imply an upward deepening and a decrease in depositional energy (shoreline retreat) while the subsequent coarsing-upward sequence observed would depict an increase in depositional energy and shallowing upwards typical of a tidally influenced fluvial environments such as river 
mouth bar or delta front (Catuneanu, 2002). The overall implication is retrogradation and progradation of these clastic sediments.

Moreso, cumulative log probability curves of all samples collected (Figure 16a and 16b) show both two and three segment curves corresponding to suspension, saltation and traction fractions/loads of Visher (1969). While Awi Formation and Amaseri Sandstone are characterized by essentially two segment curves that are typical of fluvial environments (distributary channel and point bar), Agbani Sandstone is characterized by two and three segment log probability curves that indicate a fluvial to tidally influenced environment (channel and distributary mouth bar). From a bivariate plot of sorting against skewness by Friedman (1967) it was revealed that all sand samples analyzed are fluvial. The results from multivariate parameters revealed the sand bodies to be of fluvial deposits (Sahu, 1964). This further established the results from bivariate and univariate parameters. The variance value from paleocurrent analysis of Agbani Sandstone is 33.2 and it indicates that Agbani Sandstone was deposited in a fluvio-deltaic environment (Table 5) (Steinmetz, 1962).

Table 5. Paleocurrent analysis data for Agbani sandstone at Ugwueme

\begin{tabular}{|c|c|c|c|c|c|c|c|c|}
\hline $\mathbf{S} / \mathbf{N}$ & $\begin{array}{c}\text { Azimuth } \\
\text { (A) }\end{array}$ & $\begin{array}{l}\text { Dip } \\
\text { (D) }\end{array}$ & $\begin{array}{l}\text { Sin } \\
\text { (A) }\end{array}$ & $\begin{array}{l}\text { Cos } \\
\text { (A) }\end{array}$ & $\begin{array}{l}\text { Cos } \\
\text { (D) }\end{array}$ & $\mathrm{b}=\operatorname{Cos}\left(\mathrm{A}^{*} \mathrm{D}\right)$ & $\mathrm{a}=\operatorname{Sin}(\mathrm{A})^{*} \operatorname{Cos}(\mathrm{D})$ & $(A Z-M V A)^{2}$ \\
\hline 1. & 180 & 16 & 0 & -1 & 0.9613 & -0.9613 & 0 & 1 \\
\hline 2. & 180 & 18 & 0 & -1 & 0.9511 & -0.9511 & 0 & 1 \\
\hline 3. & 188 & 20 & -0.1392 & -0.9903 & 0.9397 & -0.9306 & -0.1308 & 81 \\
\hline 4. & 172 & 20 & 0.1392 & -0.9903 & 0.9397 & -0.9306 & 0.1308 & 49 \\
\hline 5. & 185 & 26 & -0.0872 & -0.9962 & 0.8988 & -0.8988 & -0.0784 & 36 \\
\hline 6. & 176 & 20 & 0.0698 & -0.9976 & 0.9397 & -0.9374 & 0.0656 & 9 \\
\hline 7. & 178 & 18 & 0.0349 & -0.9994 & 0.9511 & -0.9505 & 0.0332 & 1 \\
\hline 8. & 166 & 18 & 0.2419 & -0.9703 & 0.9511 & -0.9229 & 0.2301 & 169 \\
\hline 9. & 172 & 16 & 0.1392 & -0.9903 & 0.9613 & -0.9520 & 0.1338 & 49 \\
\hline 10. & 190 & 18 & -0.1736 & -0.9848 & 0.9511 & -0.9367 & -0.1651 & 121 \\
\hline 11. & 176 & 28 & 0.0698 & -0.9976 & 0.8829 & -0.8808 & 0.0616 & 9 \\
\hline 12. & 180 & 22 & 0 & -1 & 0.9272 & -0.9272 & 0 & 1 \\
\hline 13. & 182 & 16 & -0.0349 & -0.9994 & 0.9613 & -0.9607 & -0.0335 & 9 \\
\hline 14. & 184 & 10 & -0.0698 & -0.9976 & 0.9848 & -0.9824 & -0.0687 & 25 \\
\hline 15. & 182 & 22 & -0.0349 & -0.9994 & 0.9272 & -0.9266 & -0.0324 & 9 \\
\hline 16. & 176 & 20 & 0.0698 & -0.9976 & 0.9397 & -0.9374 & 0.0655 & 9 \\
\hline 17. & 176 & 12 & 0.0698 & -0.9976 & 0.9781 & -0.9758 & -0.0683 & 9 \\
\hline 18. & 182 & 18 & -0.0349 & -0.9994 & 0.9511 & -0.9505 & -0.0332 & 9 \\
\hline 19. & 176 & 22 & 0.0698 & -0.9976 & 0.9272 & -0.9250 & 0.0647 & 9 \\
\hline \multirow[t]{2}{*}{20.} & 184 & 16 & -0.0698 & -0.9976 & 0.9613 & -0.9590 & -0.0671 & 25 \\
\hline & & & $\sum 0.2599$ & $\sum-19.903$ & & & & $\sum 631$ \\
\hline
\end{tabular}

$$
\begin{gathered}
\text { Mean vector Azimuth }=\operatorname{Tan}^{-1}\left[\left(\sum \operatorname{Sin} A\right) /\left(\sum \operatorname{Cos} A\right)\right] \\
\text { Where } \sum \operatorname{Sin} A=0.2599 \\
\sum \operatorname{Cos} A=-19.903 \\
\text { Therefore, } M V A=\operatorname{Tan}^{-1}[(0.2599) /(-19.903)]=\operatorname{Tan}^{-1}(-0.0131)=-0.75 \\
\text { Hence } M V A=-0.75+180=179^{0} \\
\text { Variance }=\sum\left[(\text { Ai-MVA })^{2} /(N-1)\right] \\
A Z=\text { azimuth } \\
M V A=\text { Computed mean vector azimuth }\left(179^{\circ}\right) \\
N=\text { total number of outcome (20) }
\end{gathered}
$$

Therefore, Variance $=33.2105$ 


\subsubsection{Provenance}

Ternary plots for framework components of sandstones sandstone classification (quartz, feldspar and rock fragment) (Folk, 1968) revealed that the Awi Formation are subarkosic arenites while those of Amaseri Sandstone are sublitharenites. Samples from Agbani Sandstone plotted within the subarkosic; sublitharenite and quartz arenite fields (Figure 22). It was observed that the quartz arenites of Agbani Sandstone are essentially products of leaching, alteration and possibly longer distance of transport from provenance. This is reflected in the nature of grain (Figure 20e).

The predominance of angular to subangular grains in most samples studied is suggestive of near source (Folk, $1974)$ and this together with the high percentage $(>5 \%)$ of clay matrix accounts for the textural immaturity to submaturity observed in all samples from Awi and Amaseri. Agbani Sandstone on the other hand, is comprised of texturally immature to mature sand bodies that are alternating. The implication of this is that, there are possibly two alternating sources of sediment supply. Compositionally, the sand deposits of Awi Formation and Amaseri Sandstone are submature while those of Agbani Sandstone range from submature to supermature. The discrepancy in levels of maturity texturally and mineralogically can be attributed to factors such as a humid paleoclimate since it is of common knowledge that humid climates produce sands with higher proportion of quartz and lower proportions of labile components such as feldspar and lithic fragments. This is as a result of rapid weathering and as such, mineralogical maturity is facilitated at the expense of textural maturity.

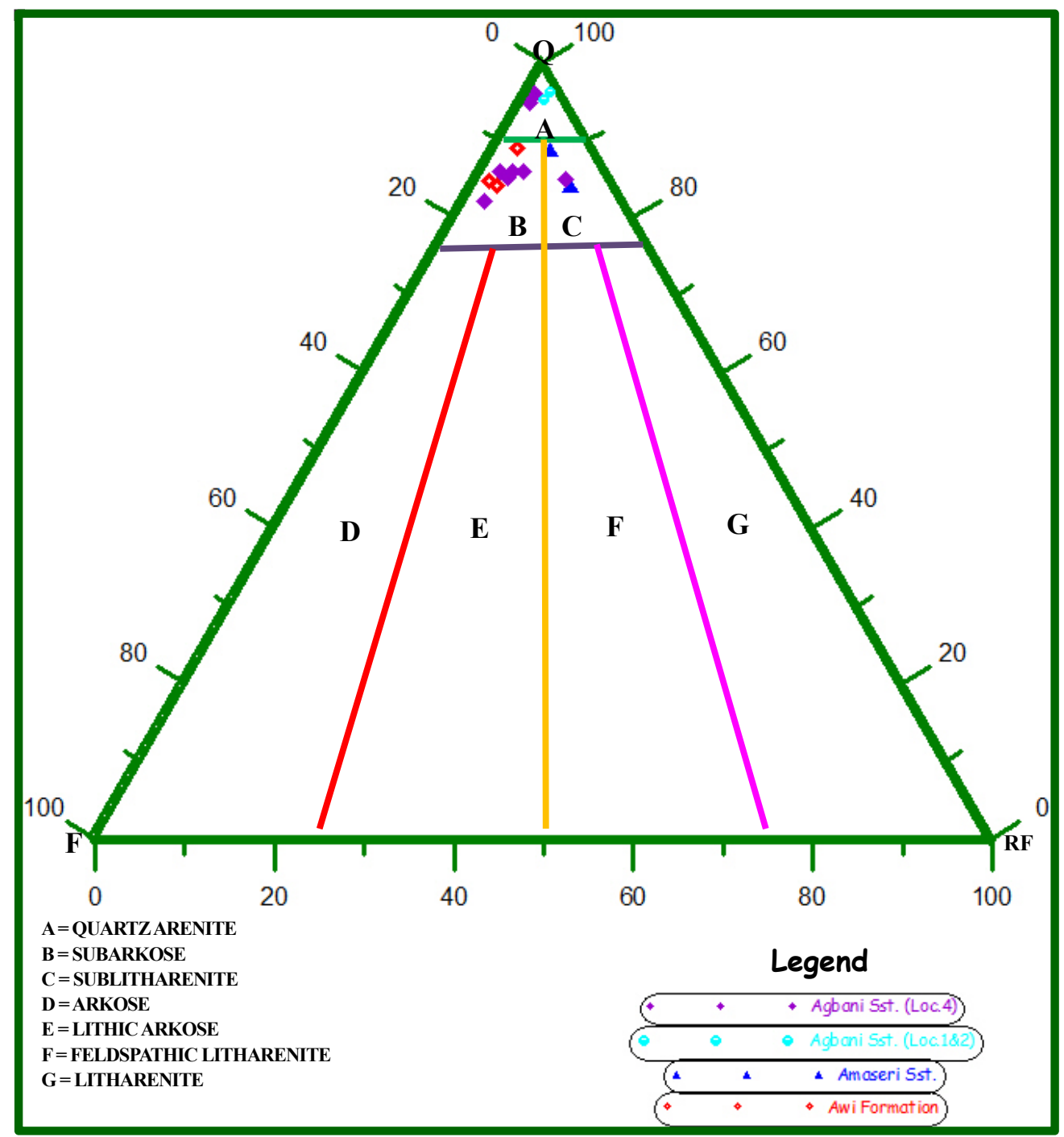

Figure 22. Ternary diagram of framework composition of Awi Formation, Amaseri and Agbani sandstones (After Folk, 1968) 
The Mean Vector Azimuth (MVA) from the paleocurrent analysis is 179Az (Table 5). This value and the paleocurrent pattern reflected in the rose diagram (Figure 19) for Agbani Sandstone suggests an essentially southerly direction of current flow at the time of deposition, while the provenance was from the north. Considering the above, together with proximity, textural and mineralogical properties of the sandstone in question, the Northeastern (Obudu Plateau) and/or Southeastern (Oban Massif) Basement Complexes would be the most probable source(s). The presence of both plutonic and metamorphic quartz in all samples studied is indicative of a basement terrain source, while the absence of volcanic rock fragments in all samples suggests a non-volcanic source (Moorehouse, 1959). The presence and amount of labile minerals such as feldspars in samples representative of Awi Formation and some of Agbani Sandstone, is suggestive of a primary rather than a reworked source (Pettijohn et al., 1973). Average ratios for monocrystalline to polycrystalline quartz for Awi Formation, Amaseri and Agbani Sandstone is given as; 4:5, 2:5, and 18:23 respectively. These ratios indicate a relatively higher concentration of polycrystalline quartz in the total quartz fraction (Table 3). Although in the quartz arenites, the monocrystalline quartz with straight extinction dominates, the more common variety of the polycrystalline quartz is the stretched metamorphic quartz which is indicative of shearing or straining in the absence of recrystallization. This probably suggests that these rocks (especially Agbani and Amaseri Sandstones) have been affected by some level of stress greater than that which would have being caused by just overburden pressure (Santonian Orogeny?). The presence of polycrystalline quartz made up of more than 5 individual grains and strong undulosity points to a metamorphic source for these formations.

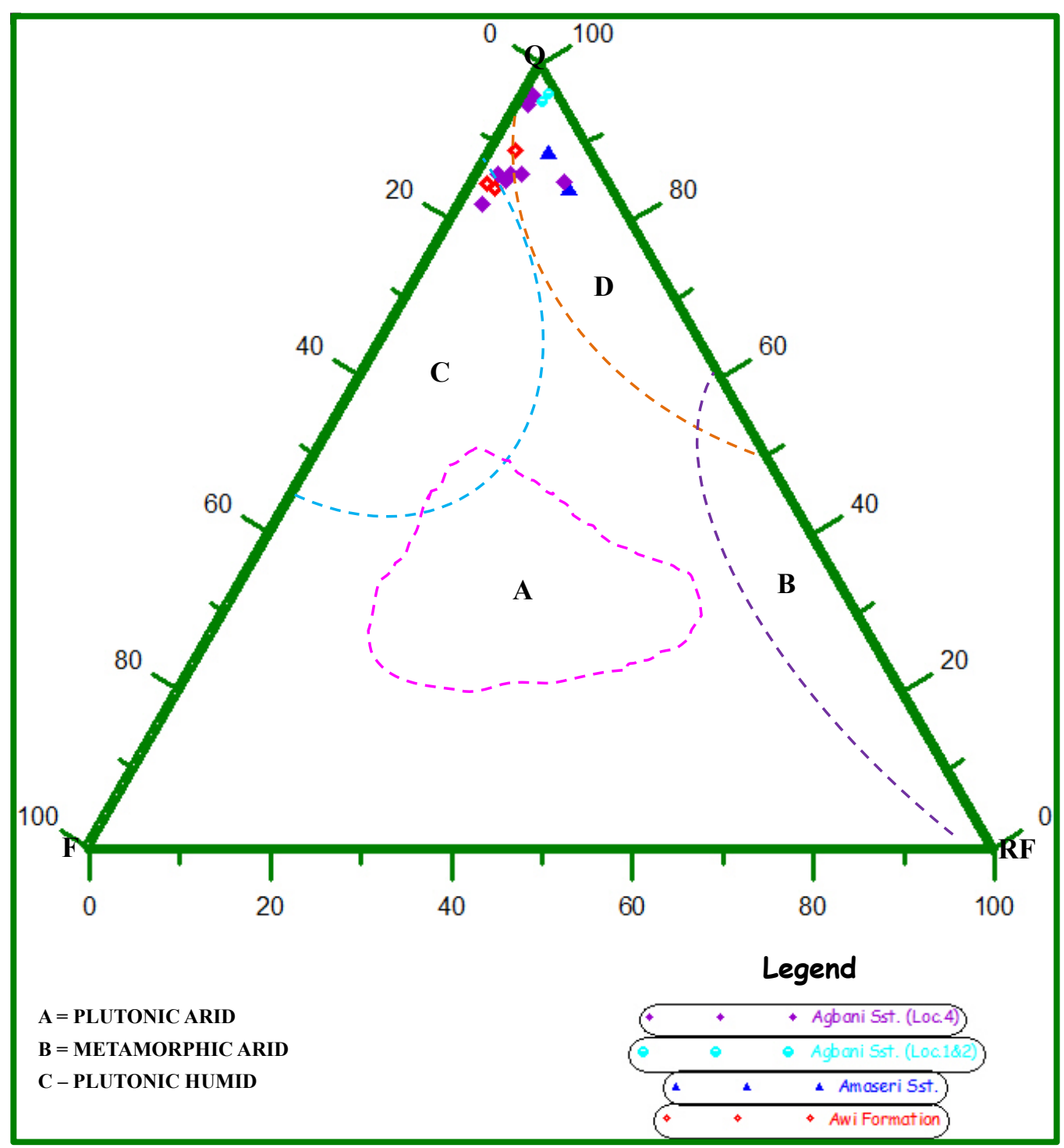

Figure 23. Paleoclimatic setting of Awi formation, Amaseri and Agbani Sandstone (after Suttner et al., 1981) 
The QFRF (quartz, feldspar and rock fragment) ternary diagram of Suttner et al. (1981) was used for delineating paleoclimatic settings. Although all samples from Awi and Agbani plotted and were evenly spread within the plutonic humid and metamorphic humid fields, samples from Amaseri plotted only in the metamorphic humid field (Figure 23). This implies that the Oban Massif and the Northeastern basement were subjected to humid climatic conditions during the Lower to early Upper Cretaceous times and this interpretation is consistent with that of Hoque (1976).

QFRF ternary plot by Dickinson (1982) used for typing provenances and inferring paleotectonic settings revealed that all the sampled sandstone units were sourced from a Craton Interior with the exception of Amaseri Sandstone which plotted in the Quartzose Recycled field (Figure 24). The QFRF ternary plot of Dickinson and Suczek (1979), show that thesandstone deposits of Awi Formation are products of a continental block provenance while Amaseri and Agbani Sandstone are sourced from both continental block and recycled orogen provenances (Figure 25).

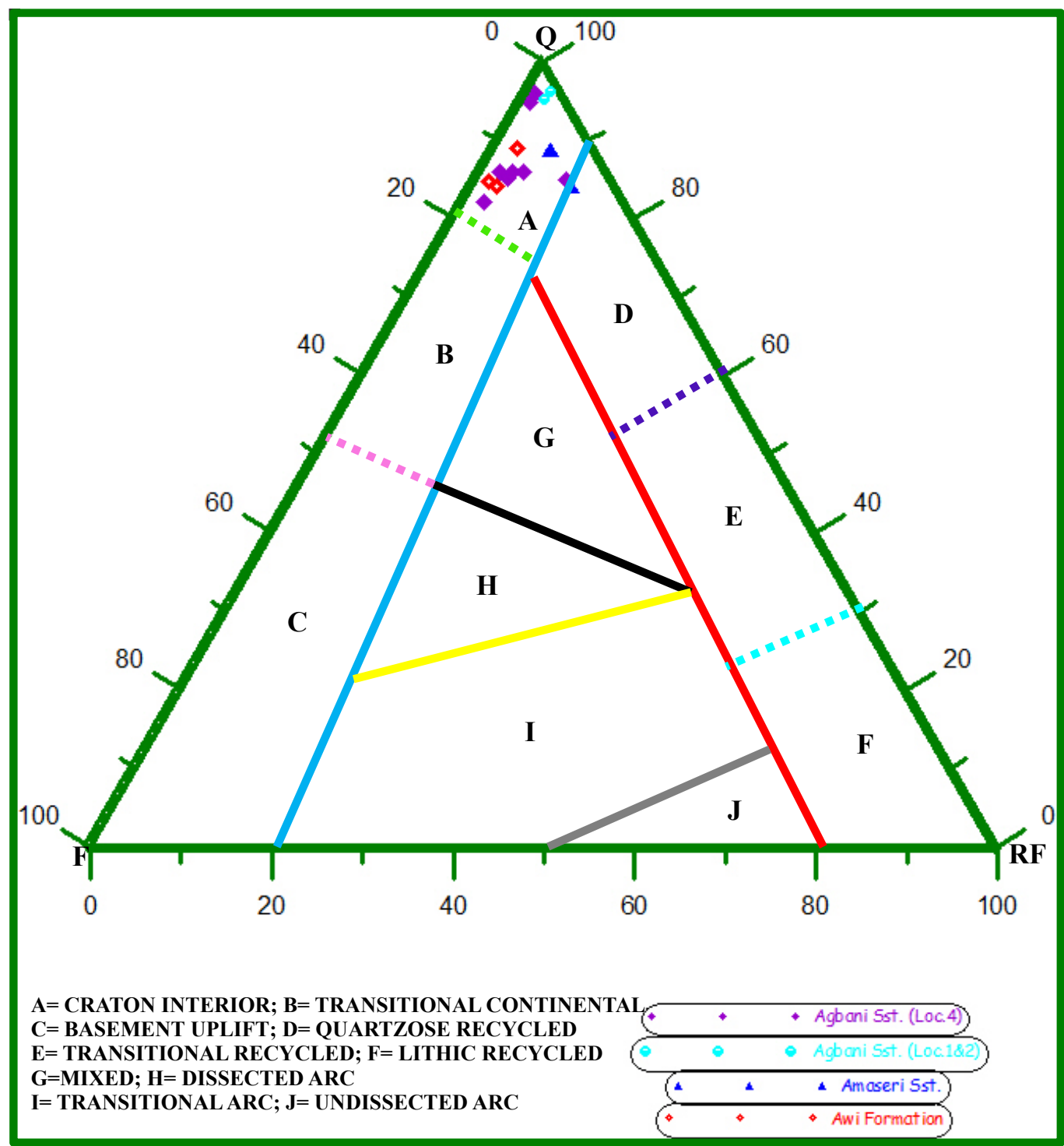

Figure 24. Paleotectonic setting of Awi Formation, Amaseri and Agbani sandstones (after Dickinson, 1982) 


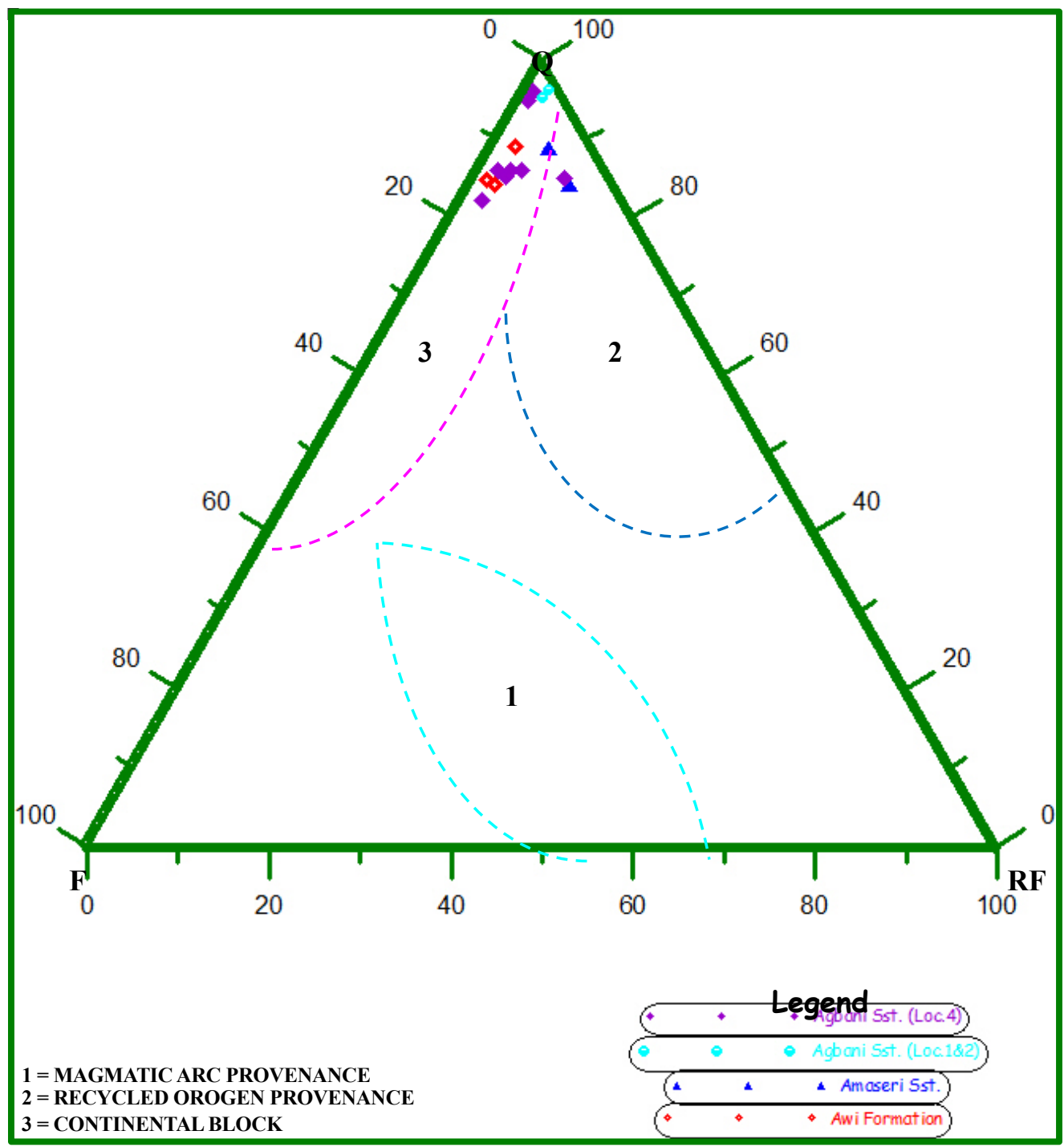

Figure 25. Paleotectonic setting of Awi Formation, Amaseri and Agbani Sandstones (after Dickinson and Suczek, 1979)

The fact that most of these sandstone units were derived from a continental block provenance would explain why they are mostly texturally immature. This is because, in the setting proposed, two tectonic sources are possible. If the continental block has recently split as a result of continental rifting, sands shed from fault bounded uplifts of the continental basement will accumulate in the troughs not far from their source and as such, will not undergo much transportation. Moreso, the rapid erosion from the high relief areas would give rise to sandstones that are quartzo-feldspathic (arkoses). But in the case of the sandstones under study, they were either probably subjected to a humid climate which altered the mineralogy to give rise to subarkoses instead of arkoses as would be expected or the sands were derived from high topographic areas located long distances from the depositional areas and as such, the sands are more quartz rich, showing a higher degree of mineralogical maturity. The inferred paleotectonic settings seem more likely to be correct since it corresponds with the tectonic history and setting of the Benue Trough as proposed by Olade (1975). It is therefore pertinent to point out that the change in sandstone type or difference in composition of sandstones as one moves from older (Awi Formation) to younger (Agbani Sandstone) formations is due to factors such as nature of provenance relief, distance of transport, rates of sedimentation, diagenesis and leaching since all the sandstones are believed to be derived from a common source (Obudu Plateau and/or Oban Massif). 


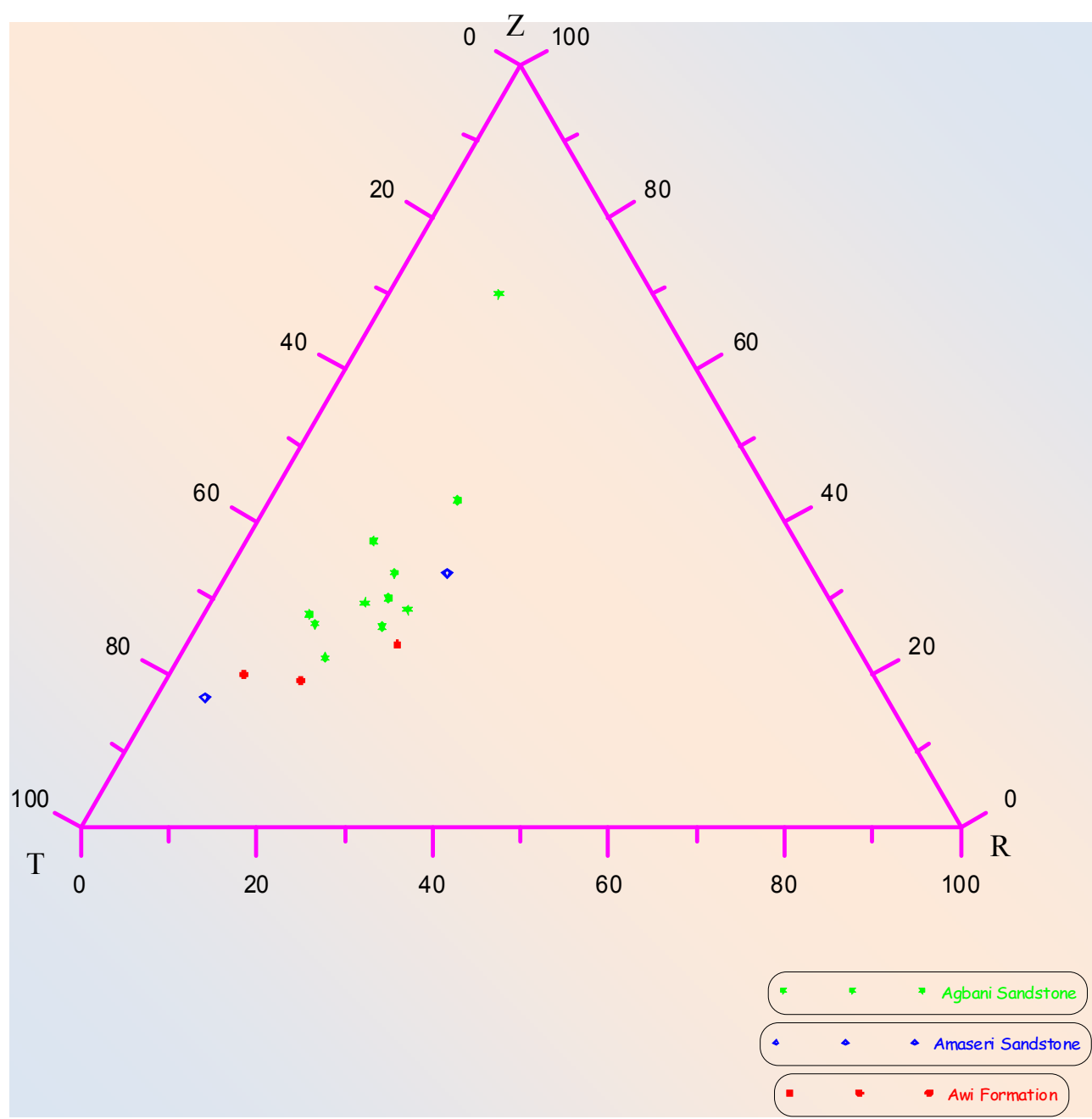

Figure 26. Ternary plot of Normalized ZTR Abundance for Awi Formation, Amaseri and Agbani sandstones

The number of heavy mineral species identified in all samples studied is given as follows: 11 (Awi Formation), 9 (Amaseri Sandstone) and 9 (Agbani Sandstone). The heavy mineral assemblages present in all samples studied, show that zircon, tourmaline, rutile, hornblende, garnet and staurolite are common. Mineral species such as Kyanite are peculiar to Awi Formation and Agbani Sandstones, apatite was found only in a single sample from Awi Formation, absent from Amaseri Sandstone and abundant in samples from Agbani Sandstone. Sillimanite is rare in Awi Formation and Agbani Sandstone but is common in Amaseri Sandstone. Topaz was found only in Awi Formation and Amaseri Sandstone but completely absent from Agbani Sandstone. Spinel (hercynite) and Zoisite were found only in Agbani Sandstone and Awi Formation respectively. The presence of zircon, topaz and apatite points to acid igneous rocks as source, while tourmaline, rutile, hornblende, and garnet indicate a combination of both acid igneous rocks and contact to regionally metamorphosed rocks as sources. Minerals such as sillimanite, staurolite, kyanite, zoisite and spinel (hercynite) are typical pointers to solely metamorphic rocks as source (Mange \& Maurer, 1992). As already stated in the heavy mineral descriptions, most of the zircon, tourmaline and rutile identified are euhedral and prismatic indicating closeness to source area. According to Mange and Maurer (1992), zircons of arkoses are mostly sharp euhedral crystals or euhedral grains with rounded terminations (Figure $21 \mathrm{~A}, \mathrm{~B}$, and C) but well rounded forms are not common.

The ZTR indices calculated for all samples show that they are mineralogically mature (74.1-94.4\%). A ternary plot adapted from Hubert (1962) for normalized values for zircon, tourmaline and rutile showed most samples plotting closer to the tourmaline apogee and this reflects the abundance of tourmaline in almost all samples (Figure 26). 


\section{Conclusion}

Generally, the field observations such as sedimentary structures and grain size analysis used for this study have establish the siliciclastic deposits of the Lower Benue Trough as products of a fluvial to tidally influenced fluvial (fluvio-deltaic) environments. These deposits are sandstone units of Awi Formation, Amaseri Sandstone and Agbani Sandstone. The kinetic energy of the transporting medium of these sediments based on univariate parameters such as mean size, sorting, skewness and kurtosis has been established to be high to moderate during the time of deposition. Sedimentary structures such as planar cross beds and ripple laminations have also been used to explain the nature of the stream power at the time deposition. Thin section petrography was effectively used to classify these siliciclastics into subarkosic arenites (Awi Formation and Agbani Sandstone), sublitharenites (Amaseri and Agbani Sandstones), and quartz arenites (Agbani Sandstone) derived mainly from a continental block provenance under humid climates. It was also observed, that these sediments become texturally immature-submature-mature as one moves from the oldest (Awi) formation to the youngest (Agbani). This has been attributed to several factors already stated in this report. The compositional framework of the rocks under study has also pointed to a basement terrain as source and in this case it is considered that the Northeastern (Obudu Plateau) and Southeastern (Oban Massif) are the most likely sources. Heavy mineral studies from the present study have shed more light on the closeness of these siliciclastic deposits to their source area and their high mineralogical maturity. This study has therefore been able to establish the depositional environment, provenance and nature of the pre-Santonian siliciclastic deposits of the Lower Benue Trough based on their sedimentological characteristics.

\section{References}

Amajor, L. C. (1990). Petrography and Characteristics of Albian and Turonian Sandstones, South-Eastern Nigeria: In C. O. Ofoegbu, (Eds.), The Benue Trough Structure and Evolution. Braunschweig (pp. 39-57). Wiesbaden: Vieweg.

Assees, O. (1989). Review of Stratigraphy, Sedimentation and Structure of the Niger Delta. In L. C. A. Kogbe (Ed.), Geology of Nigeria (2nd ed.) (pp. 311-324). Lagos: Elizabethan Publishing Company.

Awasthi, A. K. (1970). Skewness as an Environmental Indicator in the Solani River System, Roorkee (India). Sedimentary Geology, 4, 177-183. http://dx.doi.org/10.1016/0037-0738(70)90010-2

Banerjee, K. (1980). A Subtidal Bar Model for the Ezeaku Sandbodies, Nigeria. Sed. Geol., 25, 291-309. http://dx.doi.org/10.1016/0037-0738(80)90066-4

Benkhelil, M. G., Ponsard, J. F., \& Saugy, L. (1989). The Bornu-Benue Trough, the Niger Delta and its Offshore: Tectono-sedimentary reconstruction during the Cretaceous and Tertiary from geophysical data and geology. In C. A. Kogbe (Ed.), Geology of Nigeria ( $2^{\text {nd }}$ ed.) (pp. 277-309). Lagos: Elizabethan Publishing Company.

Burke, K. C. (1976). Development of Graben Associated with the Initial Ruptures of the Atlantic Ocean. Tectonophysics, 36, 93-112. http://dx.doi.org/10.1016/0040-1951(76)90009-3

Burke, K. C., Dessauvagie, T. F. J., \& Whiteman, A. J. (1972). The Geological History of the Benue Valley and adjacent areas. In T. F. J. Dessauvagie \& A. J. Whiteman (Eds.), African Geology. University of Ibadan Press. Journ. Min. Geol., 15, 187-205.

Catuneanu, O. (2002). Sequence Stratigraphy of Clastic Systems: Concepts, Merits, and Pitfalls. Journal of African Earth Sciences, 35(1), 1-43. http://dx.doi.org/10.1016/S0899-5362(02)00004-0

Cheel, R. J. (2005). Introduction to Clastic Sedimentology. United Kingdom: Chapman and Hall, p. 139.

Dessauvagie, T. F. J. (1972). Biostratigraphy of the Odukpani (Cretaceous) type section, Nigeria. In T. F. J. Dessauvagie \& A. J. Whiteman (Eds.). African Geology (pp. 207-218). Ibadan, Nigeria: University of Ibadan Press..

Dickinson, W. R. (1982). Compositions of Sandstones in Circum-Pacific Subduction Complexes and Fore-arc Basins. AAPG Bulletin, 66, 121-137.

Dickinson, W. R., \& Suczek, C. A., (1979). Plate Tectonics and Sandstone Compositions. Bull. Am. Assoc. Petrol. Geol., 63, 2164-2182.

Folk, R. L. (1974). Petrology of Sedimentary Rocks (2nd ed.) (p. 182). Austin, Texas: Hemphill Publ. Co.

Folk, R. L., \& Ward, W. L. (1957). Brazus River Bar: A Study of the Significance of Grain Size Parameters. Journal of Sed. Pet., 27, 2-27. 
Freeth, S. J. (1990). The Origin of the Benue Trough. In: C. O. Ofoegbu (Ed.), The Benue Trough Structure and Evolution. Friedr (pp. 217-227). Wiesbaden: Vieweg ans Sohn Braunschweig, Germany.

Friedman, G. M. (1967). Dynamic process and statistical parameters compared for size frequency distribution of beach and river sands. Journ. Sed. Petrol., 37, 327-354.

Galehouse, J. S. (1971). Counting grain mounts: Number percentage vs. number frequency. J. Sed. Petrology, 22, 125-145.

Grant, N. K. (1971). South Atlantic, Benue Trough and Gulf of Guinea Cretaceous Tripple Junction. Geol. Soc. Am. Bull., 28, 2295. http://dx.doi.org/10.1130/0016-7606(1971)82[2295:SABTAG]2.0.CO;2

Hoque, E. M. (1977). Petrographic Differenciation of Tectonically Controlled Cretaceous Sedimentary Cycles, Southern Nigeria. Bull. Sed. Geol., 17, 235-245.

Hoque, M. (1976). Significance of Textural and Petrographic Attributes of Several Cretaceous Sandstones, Southern Nigeria. Bull. Geol. Soc. India, 17, 514-521.

Hubert, J. F. (1962). A Zircon-Tourmaline-Rutile maturity index and the interdependence of the composition of heavy mineral assemblages with the gross composition and texture of sandstones. J. Sed. Petrology, 32, 440-450.

King, L. C. (1950). Outline and Disruption of Gondwanaland. Geol. Mag., 87, 353-359. http://dx.doi.org/10.1017/S0016756800077311

Kogbe, C. A. (1989). The Cretaceous and Paleogene Sediments of southern Nigeria. In C. A. Kogbe, (2nd ed.), Geology of Nigeria (pp. 325-334). Lagos: Elizabethan Publishing Company.

Mange, M. A., \& Maurer, W. H. (1992). Heavy Minerals in Colour. London, UK: Chapman and Hall, pp. 1-145. http://dx.doi.org/10.1007/978-94-011-2308-2

Moorehouse, W. W. (1959). The Study of Thin-sections. New York: Harpers.

Murat, R. C. (1972). Stratigraphy and Paleogeography of the Cretaceous and Lower Tertiary in Southern Nigeria. In T. F. J. Dessauvagie \& A. J. Whiteman (Eds.). African Geology (pp. 251-256). Nigeria: University of Ibadan Press.

Nton, M. E. (1999). Sedimentology and Depositional Environment of the Calabar Flank, Southeastern Nigeria. Journ. Min. Geol., 33(1), 23-36.

Nwajide, C. S. (1990). Cretaceous Sedimentation and Paleogeography of the Central Benue Trough. In C. O. Ofoegbu (Ed.), The Benue Trough Structure and Evolution International Monograph Series (pp. 19-38). Braunschweig.

Obaje, N. G., Ulu, O. K., \& Petters, S. W. (1999). Biostratigraphic and Geochemical Controls of Hydrocarbon Prospects in the Benue Trough and Anambra Basin, Nigeria. NAPE Bull., 14(1), 18-54.

Offodile, M. E. (1976). The Geology of the Middle Benue, Nigeria. Publications from the Paleontological Institute of the University of Uppsala, Spec. 4, p. 166.

Offodile, M. E. (1989). A Review of the Geology of the Cretaceous of the Benue Valley. In: Kogbe, C. A. (2 ${ }^{\text {nd }}$ ed.), Geology of Nigeria. Lagos: Elizabethan Publishing Company, pp. 365-376.

Ofoegbu, C. O. (1990). The Benue Trough Structure and Evolution. Braunschweig; Wiesbaden: Vieweg, Germany.

Okezie, C. N. (1984). Geological Map of Nigeria. Geological Survey division, Ministry of Mining and Power. Nigeria.

Olade, M. A. (1975). Evolution of Nigerian Benue Trough (Aulacogen): A Tectonic. Model. Geol. Mag., 112, 575-583. http://dx.doi.org/10.1017/S001675680003898X

Petters, S. W. (1978). Stratigraphic Evolution of the Benue Trough and its implications for the Upper Cretaceous Paleogeography of West Africa. Journ. Geol., 86, 311-322. http://dx.doi.org/10.1086/649693

Petters, S. W., \& Ekweosor, C. M. (1982). Petroleum Geology of the Benue Trough and southeastern Chad Basin, Nigeria. AAPG Bull., 66, 1141-1149.

Petters, S. W., (1983). Gulf of Guinea Planktonic Foraminiferal Biochronology and Geological History of the South Atlantic. Journ. of Foraminiferal research, 13(1), 32-59.

Pettijohn, F. J., Potter, P. E., \& Siever, R. (1973). Sand and Sandstones (1st ed.). New York: Springer Verlag. 
Reyment, R. A. (1965). Aspect of the Geology of Nigeria. University of Ibadan Press, pp. 46-80.

Reyment, R. A., \& Morner, N. A. (1977). Cretaceous transgressions and regressions exemplified by the South Atlantic. Spec. Pap. Paleont. Soc. Japan, 21, 247-264.

Sahu, K. D. (1964). Depositional Mechanisms for the Size Analysis of Clastic Sediments. Journ. Sed. Pet., 37, 73-83.

Selley, R. C (1966). Palaeocurrent and Sediment Transport in Near Shore Sediment of Sincte Basin. Libya. $J$. Geol., 75(2), 215-222. http://dx.doi.org/10.1086/627247

Simons, D. B., Richardson, E. V., \& Nordine, C. F. (1965). Sedimentary Structure Generated by Flow in Alluvial Channels. Spec. Publ. - Soc. Econ. Paleontol. Minerals, 12, 34-52.

Steinmetz, G. (1962). Paleocurrent and Provenance Determination of Sandstone Mustang Island, Texas. Journ. Sed. Pet., 30, 753-780.

Suttner, L. J., Basu, A., \& Mach, G. H. (1981). Climate and the Origin of Quartz-arenites. Jour. Sed. Petrol., 51, 1235-1246.

Visher, G. S. (1969). Grain-size Distribution and Depositional Processes. Journ. Sed. Pet., 34, 1074-1106.

Whiteman, A. J. (1980). Nigeria: its Petroleum Geology, Resources and Potential. London, Graham and Trotman. 1, p. 166.

Wright, J. B. (1981). Review of the Origin and Evolution of the Benue Trough in Nigeria. In L. C. A. Kogbe (Ed.), Geology of Nigeria (pp. 348-359). Lagos: Elizabethan Publishing Company. 